\title{
MEDICINAL PLANTS USED IN STREET MARKETS IN DIFFERENT REGIONS OF BRAZIL
}

\author{
Jaqueline Cibene Moreira Borges ${ }^{1}$, Ana Karine Fernandes Lemos ${ }^{2}$, Thalita Melo França Costa ${ }^{2}$, \\ Vanderson Ramos Mafra', Saulo José Lima Júnior ${ }^{3}$, Taciano Peres Ferreira ${ }^{4}$, Valéria Maciel \\ Cordeiro $^{2}$, Natallia Moreira Lopes Leão ${ }^{1}$, Andreisa Prieb ${ }^{3}$, Yara Silveira ${ }^{1}$, Christiane Rodrigues de \\ Paula Marques $^{2}$, Nayanne Deusdará Escobar ${ }^{5}$, Marco Túlio Borges Sousa ${ }^{6}$ and Sara Falcão de Sousa ${ }^{1 *}$
}

1Pharmacist and Professor at the University of Gurupi, Unirg, Av. Rio de Janeiro, № 1585 - St. Central, Gurupi, 77403-090, Tocantins, Brazil; ²Pharmacist, Unirg, Av. Rio de Janeiro, № 1585 - St. Central, Gurupi, 77403-090,

Tocantins, Brazil; ${ }^{3}$ Pharmacist and medical student at the University of Gurupi, Unirg, Av. Rio de Janeiro, № 1585 - St. Central, Gurupi, 77403-090, Tocantins, Brazil; ${ }^{4}$ Collegiate of Environmental Chemistry, Federal

University of Tocantins, Av. Rio de Janeiro, № 1585 - St. Central, Gurupi, 77403-090, Tocantins, Brazil; 5Physician and medical student at the University of Gurupi, Unirg, Av. Rio de Janeiro, № 1585 - St. Central, Gurupi, 77403-090, Tocantins, Brazil; ${ }^{6}$ Doctor, Unirg, Av. Rio de Janeiro, № 1585 - St. Central, Gurupi, 77403090, Tocantins, Brazil

\section{ARTICLE INFO}

Article History:

Received $26^{\text {th }}$ March, 2020

Received in revised form

$04^{\text {th }}$ April, 2020

Accepted $19^{\text {th }}$ May, 2020

Published online $25^{\text {th }}$ June, 2020

\section{Key words:}

Medicinal Plants,

Street Markets,

Ethnobotany.

*Corresponding author:

Sara Falcão de Sousa

\begin{abstract}
In Brazil, markets and street markets emerged in 1841 as a solution for the regional supply of products. Street markets and municipal markets constitute a privileged space for traditional expressions and cultures about their ethnobotanical heritage since these places are centers of large numbers of information, underlying an environment of intense cultural exchanges. Bibliographic surveys were carried out on medicinal plants used in Street markets in different regions of Brazil. Where the objectives were to identify the families and species of medicinal plants used in different regions of Brazil, the common names and frequency of citations were identified regarding the mode of use of medicinal plants in the Street markets and it was verified which parts of the most cited plants in Street markets in different regions of Brazil were verified, the most cited therapeutic indications were verified. The most cited medicinal plants were "stonebreaker" plants Phyllanthus niruri, "elderberries" Sambucus nigra, "macela" Achyrocline satureioides and "espinheira santa" Maytenus ilicifolia. The modes of use of these plants were more cited as medicinal uses $71 \%$ and ritualistic baths $27 \%$. The most used parts were leaves $60.1 \%$, flower $13.5 \%$, and bark $9.0 \%$, the families that had a higher citation were Asteraceae, Lamiaceae, and Malvaceae. Regarding the therapeutic indications, stomach diseases, flu-like symptoms, skin problems, and healing, inflammation, and diuretics were more cited. It is concluded then that the use of medicinal plants is used for various therapeutic indications.
\end{abstract}

Copyright (C) 2020, Jaqueline Cibene Moreira Borges et al. This is an open access article distributed under the Creative Commons Attribution License, which permits unrestricted use, distribution, and reproduction in any medium, provided the original work is properly cited.

Citation: Jaqueline Cibene Moreira Borges, Ana Karine Fernandes Lemos, Thalita Melo França Costa et al. "Medicinal plants used in street markets in different regions of Brazil”, International Journal of Development Research, 10, 06, 36443-36456.

\section{INTRODUCTION}

In Brazil, there is growing interest and search for traditional medicine and phytotherapy that occurs due to the current lack of resources of public health agencies and incessant price increases in allopathic drugs, as well as the side effects presented by some of these drugs (1). Moreover, the use of medicinal plants, cultivated or not, used for therapeutic purposes, is a form of treatment of very ancient origin, since indigenous, African and European cultures are the ones that most influenced the use of plants in disease treatments $(2-4)$. Therefore, the use and trade of medicinal plants have been stimulated in recent decades by the need for a growing population that seeks greater diversity and quantity of plants to be used in health care (1). According to the Ministry of Health 2007 (5) the National Program of Medicinal Plants and Herbal Medicines, in addition to having as objectives the guarantee of safe access and rational use of medicinal and herbal plants in our country, the strengthening of chains and productive 
arrangements, the sustainable use of Brazilian biodiversity and the development of the Health Production Complex HPC, also have as objectives to promote and recognize the popular and traditional practices of use of medicinal plants, herbal medicines, and home remedies. In this sense, among the policies inserted in the National Program of Medicinal Plants and Herbal Medicines 2006 (4) stands out the National Policy for the Sustainable Development of Traditional Peoples and Communities, which has great relevance for the present work because it values the groups of differentiated cultures that recognize themselves as such, have their forms of social organization, occupy and use territories and natural resources for their cultural reproduction, social, religious, ancestral and economic, using knowledge, innovations, and practices generated and transmitted by tradition. According to Martin 1995 (6), Brazil has an impressive biodiversity, traditional communities make use of medicinal plants, these plants are the raw material for the production of herbal medicines and other medicines. The term traditional knowledge refers to the local knowledge of a population about the natural environment where they live, where they are under study. The use of medicinal plants has become a widespread practice in folk medicine (7). According to Souza 2011 (8), researching with medicinal plants can contribute to improve the use of plant resources by the local population, as well as subsidize indicators for new and effective drugs in the fight against various pathologies. Starting from this context Souza 2011 (8), had the objective of surveying medicinal plants commercialized at the free fair in the city of Esperança - PB.

Therefore, it is always valid to conduct studies that involve and value regional culture, popular medicine, emphasizing that residents of each region of Brazil have different customs and behaviors. Climate, the influence of colonization in these different regions of Brazil, historical rescue are factors that greatly influence the degree of knowledge about medicinal plants. Therefore, conducting a bibliographic survey on the study of medicinal plants sold in Street markets in different regions of Brazil becomes extremely valuable to analyze and value the popular knowledge. Also, this study will provide an analysis of the most used species in each region, the similarities and differences in research results, and the most important is to compare popular use, the ethnopharmacological study with scientifically proven studies because free markets are the places where there is a greater demand for this ethnobotanical knowledge. After all, they are free markets that have as one of the representatives, sellers, with a wealth of knowledge about medicinal plants. This work aims to verify the medicinal plants used in Street markets in different regions of Brazil, through a bibliographic survey, identify the families and species and the common names of medicinal plants, the most used parts and for which they are used, and which therapeutic indications are most cited.

\section{LITERATURE REVIEW}

2.1 Folk medicine and traditional medicine: The "in natura" or pre-processed plant used by populations without medical recommendations is a practice called "Folk Medicine" and this practice has its risks, such as the difficulties in establishing its doses, dosages and, in some cases, the true identity of some species (9). França et al. 2008 (10) conducted a study in Campina-Paraíba, Brazil, in the informal market of medicinal plants, from August 2006 to June 2007, in which they sought to verify about the use of medication and/or herbal medicine, and whether herbaria working in the city, provide the necessary information for the correct use of medicinal plants; clients are instructed about possible intoxications or interaction with allopathic drugs and criteria are used for the commercialization of herbal medicines. The samples were composed of accessibility, totaling 14 "sellers of medicinal herbs" or "herbolarians" who agreed to participate in the research. 53.13\% live in Campo Grande-PB due to ease of travel and the access it has to farmers who harvest and select condition, and transport plant matter to the Central Market of Campo Grande- PB. Regarding the results, it is worth highlighting the origin of knowledge about phytotherapy; $21.42 \%$ learned to use herbal medicine in day-to-day contact with friends, $7.14 \%$ learned from relatives. Origin of herbs $79 \%$ of the herbolarians acquired the herbs in warehouses specialized in this product, or with an intermediary that brought them from the garden, $21 \%$ grow and harvest the herbs from their gardens and bring them to the fair.

... Currently, the economic, political, and social changes that have erupted around the world have influenced not only people's health but also on care models, the therapeutic use of natural resources used in human care (7).

Given the increasing use with medicinal plants for therapeutic purposes Rezende 2002 (11), they explain that the appearance of the use in Brazil of popular medicine comes from the indigenous culture and contribution of Africans and Europeans, in the period that was a colony of Portugal, as doctors attended more in large metropolises without attending rural areas these communities resorted to the use of medicinal plants. The traditional medicine is understood as one that uses natural knowledge and practices, passed down from generation to generation. Phytotherapy can be defined as the practice of employing medicinal plants and has shown that it is no longer a therapeutic alternative preferably used by the lower-income population (12). Several studies have already been carried out to demonstrate the importance of phytotherapy in the community, for example, Rezende 2002 (11) conducted an exploratory descriptive survey in the municipality of Santa Rita de Caldas, in the south of Minas Gerais, Brazil, located $200 \mathrm{~km}$ from Campinas, during July, August, September and December 1997, this research aimed at residents of the rural area of this city, to verify the occurrence of the use of herbal medicines in this population, as well as to identify the plants used more frequently, a form of use and thus compare their effects with those described in the literature. It was noticed that the plants used were those already existing in the region, and phytotherapy was used for purposes similar to those described in the literature, aiming at the prevention and treatment of diseases. In Brazil, there is growing interest and search for traditional medicine and phytotherapy (13). It is believed that this fact is due to the current lack of resources of public health agencies and incessant price increases in allopathic drugs, as well as the side effects presented by some of these drugs (14). The World Health Organization WHO estimates that about $80 \%$ of the world's population depends on plants for health care, they also report that $85 \%$ of traditional medicine involves the use of medicinal plants, their plant extracts and their active ingredients (15). These traditional populations have a specific way of life, a peculiar relationship with nature and natural resources, interacting without causing destruction and transmitting knowledge to perpetuate the group's identity (16). Studies on popular medicine have been 
deserving of increasing attention due to the contingent of information and clarifications that have been offered to science. This phenomenon has provided the use of teas, decoctions, and tinctures, causing, in most western countries, medicines of plant origin to be systematically and increasingly resumed in the prophylaxis and treatment of diseases, alongside conventional therapy (17). Phytotherapy uses from various parts of plants, such as roots, bark, leaves, fruits, and seeds according to the herbs in question (18). According to Lainetti and Brito 1980 (18), there are many forms of preparation of these medicinal plants as teas, the most used being prepared by decoction or infusion. A decoction is an act of cooking the plant, and the infusion is the act of placing already boiled water on the plant and thus being released its active principles.

Medicinal plants: Since its beginnings, the human being noticed the curative effects of medicinal plants, noting that somehow under which the medicinal vegetable was administered powder, tea, bath, and others provided the recovery of the individual's health (19). Medicinal plants are considered all fresh dried plants and those harvested fresh, which are used for the consumption of homemade tea, are therefore disregarded, any other type of plant, such as industrialized teas (20). The use of medicinal plants for the maintenance and recovery of health has occurred over time $(21,22)$ This can be proven in the study by Souza and Felfili 2006 (23), who conducted a study in the community surrounding the "Chapada dos Veadeiros" "National Park and the city of "Alto Paraíso de Goiás", Brazil, to investigate which plants were used by urban and rural populations for the treatment of diseases with phytotherapy, and their purposes, and the origin and habit of medicinal flora. It is understood that the healing power of plants is as old as the appearance of the human species on earth, because, from an early age the first civilizations realized, that some plants contained in their essences active principles, and when used to combat diseases, empirically revealed their healing power, the plants became then a strong ally to fight diseases (24). This knowledge of the peasant world, contrary to what many still think is of surprising depth and complexity, creating and recreating styles, forms, and systems of knowledge, living, and doing (25). Junqueira 2005 (26) conducted a study in the southern region of Minas Gerais, with the population of the "Gamarra Valley", rural area of "Baependi", Brazil, where he intended to gather and catalog medicinal plants, also seeking to find specialists in medicinal plants known as rooters, investigating the native plants used, and the ways of preparing home remedies, and sensitizing the community to organize a medicinal garden. Through a semi-structured interview script, they were applied in the visits, to know the plants used, how they were prepared and where they were found whether they are cultivated or native, with whom they learned to use them, diseases more frequent availability and interest in the formation of the living pharmacy. Maioli-Azevedo 2007 (1) conducted research at the Street markets in the city of Rio de Janeiro, Brazil, from May/2003 to June/2003, where they sought to identify medicinal and ritualistic plants sold at street market, verify their respective therapeutic indications and analyze the relative importance of these species sold, valuing empirical knowledge added to the herbarium. Sixty semistructured interviews and direct observation techniques were conducted with the participation of 54 "free" the 33 street market. According to Machado 2006 (27) it is understood that the use of medicinal plants aims to help and improve people's health, provided that they know how to use correctly evaluating their danger and their advantages, being able to extract information, so that they can know for which these plants can be used, making them more autonomous in the care of their health.

National Policy of Medicinal plants and herbal medicines: RENISUS is the National List of Medicinal Plants of Interest to the UHS. It consists of plant species with the potential to advance in the stages of the production chain and to generate products of interest to the Unified Health System UHS (28).

... The purpose of "RENISUS" is to subsidize the development of the entire production chain, including the actions that will also be developed by the other ministries participating in the National Program of Medicinal plants and herbal medicines, related to the regulation, cultivation/management, production, marketing and dispensing of medicinal and herbal plants. It also has the function of guiding studies and research that can support the elaboration of "RENAFITO" National List of Medicinal and Phytotherapeutic Plants, the development and innovation in the area of medicinal plants and herbal medicines. According to the Ministry of Health 2011 (28), RENISUS is of great importance to society because, through a list of medicinal plants, it makes it clear to society that plant species have efficacy and safety.

The National List of Medicinal Plants of Interest to The SUS RESINUS, lists 71 species of medicinal plants that can be used as herbal medicines in the SUS (28). Amorim 1999 (29) conducted a study in Campinas Grande, the State of Paraíba, Brazil, which sought to highlight the importance of the implementation of phytotherapy in the health network, as well as the need for the university to integrate into this process through the activity of teaching, research, and extension of services to the community. It was found that $82.9 \%$ of the families had a specialist in medicinal plants who used to use par themselves and for their family, medicine prepared with plants. As for the indications, most coincided with those of the scientific literature. Several studies sought to verify the knowledge and popular use of medicinal plants, satisfaction, and use of them, as in various research; Arnous 2005 (30), in the municipality of Datas - MG, located in the mesoregion of the Jequitinhonha Valley Minas Gerais, Brazil. Semistructured questionnaires composed of 13 questions were used, focusing on socio-economic, known plants, obtaining, preparing, the reason for use and interest in cultivating a community medicinal garden, and a questionnaire was applied with the help of community health agents and nursing assistants of the Family Health Program FHP with the support of the secretary of health and the local population. The National Policy of Medicinal and Phytotherapeutic Plants PNPMF, regulation by Decree No. 5,813 of June 22, 2006 (4). According to the Ministry of Health 2006 (4) this decree no. 5,813 was implemented due to the use of herbal medicine is already in the daily life of populations and frequently. In addition to promoting the sustainable use of the components of Brazilian biodiversity leading to the generation of wealth with social inclusion and improvement of the quality of life of the most, because Brazil has 15 to $20 \%$ of the world's biodiversity. The regulation of the use of medicinal and herbal plants arose at the Alma-Ata conference in 1978 in which the WHO recommended integration by the member states of traditional medicine (4). According to the Resolution of the Collegiate Board No. 48/2004 of ANVISA, herbal medicines are medicines prepared exclusively with plants or part of 
medicinal plants. Thus, they have recognized properties of cure, prevention, diagnosis, or symptomatic treatment of disease validated in the ethnopharmacological study, technoscientific documentation, or phase 3 clinical trials (30). Tomazzoni 2006 (31) through a study in Cascavel, an extreme region of western Paraná, with coverage in the FHU area of "Nossa Senhora dos Navegantes", in the period of December 2003 and February 2004, sought to expand the knowledge about the use of medicinal plants by the community of the municipality of this municipality, aiming to subsidize the implementation of herbal medicines in the public health network. It was verified that medicinal plants for this community represent an important factor for the maintenance of health conditions being part of a preserved local knowledge of health. However, none of the interviewees indicated the use of medicinal plants with medical guidance, referring to the use as coming from the indication of friends and relatives, specialized books, self-knowledge, and often gathered all these alternatives.

Ethnobotanical study: Ethnobotany applied to the study of medicinal plants works in close complicity with ethnopharmacology, which consists of interdisciplinary scientific explorations of biologically active agents, traditionally employed or observed by certain human groups $(32,33)$. Ethnobotany, in turn, analyzes, studies and interprets the history of plants in ancient and current societies (34), and according to Ferro 2006 (35) is of enormous value to regional communities that work, produce and manipulate the action to obtain medicines, food product, and substance for raw materials. In recent years, interest has increased for ethnobotanical studies with a broader approach to this subject, research on this subject has been of enormous value, in general, it is multidisciplinary, about the valorization of the elements of biodiversity of natural ecosystems (34, 36 - 39). Pinto 2006 (40) conducted a study in rural communities of "Camboinha" and "Marambaia", located in the "Atlantic Forest" - in municipally of "Itacaré", BA, Brazil, during January, February and July/2002, in which they sought to rescue popular knowledge about the use of medicinal plants and to carry out an ethnobotanical study of the species used for medicinal purposes of these rural communities. In this study, the collection of information occurred through unstructured and structured interviews, in which 26 families were interviewed, so that the following information could be obtained: so many socio-economic data of the informants, such as ethnobotanicals name, popular, partly used, forms of preparation, dosages, application, therapeutic purposes, restrictions, as well as the degree of importance preference and or, need for the use of conventional medicine; participation of the informant in the projects monitored by IESB Institutes of Socio-Environmental Studies of southern Bahia and their perception regarding the conservation of local biodiversity and the implementation of the Environmental Protection Area EPA, Itacaré/Serra Grande. Currently, ethnobotany is being cited in the literature as one of the alternative paths that have evolved the most in recent years for the discovery of bioactive natural products $(32,33,41)$. In addition to ethnobotany including all studies concerning the mutual relationship between traditional populations and plants (42). It also addresses how people incorporate plants into their cultural practices and traditions (43). Studies the interaction between humans and plants in dynamic combinations (44). In Brazil and several other countries, the intensification of ethnobotanical studies leads to the knowledge of the species that were used and may serve as an instrument to delineate strategies for the use and conservation of native species and their potentials (45). According to Gottlieb et al. 1998 (46), ethnobotanical studies are interesting, especially in Brazil, because in its states it has a huge variety becoming one of the richest floras in the world, where $99 \%$ are not yet known chemically. Damasceno 2008 (47) conducted a study in the urban area of "Martinésia", Uberlândia, Minas Gerais, Brazil, from January 2006 to January 2007, in which they sought to investigate the plants known and/or used by informants living in the community. Through the interviews, the following information was obtained: a taxonomic study of the plants cited by community informants, popular identification of these plants in the community, evaluation of the connoisseurs of the plants in the community, evaluation of the use of the species mentioned in the survey. Ethnobotanical investigations in the Cerrado biome region are still scarce (48). The Cerrado is the second most important biome in Brazil with an area of more than 2,000,000 $\mathrm{km}^{2}$ with forest, savanna, and rural formations (49). The Cerrado is recognized as the richest savannah in the world in biodiversity (50). Therefore, ethnobotany has as characteristic the study of direct contact with traditional populations, where conviviality and proximity allow a gain of trust, thus rescuing knowledge and affinity relationships between human beings and plants (42).

Ethnopharmacological study: The ethnopharmacological study can be defined as an interdisciplinary scientific exploration of biologically active agents, traditionally employed or observed by man (51). Ethnopharmacological studies in Brazil are a great challenge since the varied Brazilian flora has been progressively destroyed (52). Ethnopharmacology is an excellent source of new substances and drugs when compared to other methods of discovery of which randomly, chemossystematic and phylogenetic (53). Ethnopharmacological research is today important tools of records and documentation of the empirical uses of medicinal plants in traditional communities, generating useful knowledge for the development of new medicines, the conservation of biodiversity, the valuations of knowledge and local cultures (54). Thus, following this reasoning, the researchers Boscolo 2008 (55) promoted a study in Quissamã, State of Rio de Janeiro during the period from February 2001 to January 2002, to rescue the plants that the community residents used in home medicine and also collect data on their biological activities that can contribute to the validations of traditional connoisseurs. Open interviews were conducted with local informants to obtain data such as place of collection, popular name, use, and parts used. Ethnopharmacological surveys carried out in Brazilian forests are promising instruments in the discovery of new drugs, since this country has high rates of biodiversity and endemism associated with an intense miscegenation process that resulted in a considerable wealth of knowledge about its flora (56). According to Elizabetsky 2004 (57), ethnopharmacology is based on information on therapeutic utilities and not on a certain chemical profile of the species, which actually through knowledge indicates possible interactions with a given biological target.

The importance of the traditional community in knowledge and use of plants: Communities considered as traditional have specific characteristics, such as a traditional group, because economic activities, historical bonding, and occupation of a given territory are important for their cultural reproduction (44). According to estimates, traditional peoples and 
communities occupy almost $25 \%$ of the national territory, but little of this is legally recognized. Also, these traditional communities have acquired, over time, a very positive connotation about biodiversity conservation (58). Medicinal plants have always been of great importance to many communities as a healing tool (59). As can be seen in the work of Morais 2005 (60) where they researched the indigenous community of "Tapebas" in the municipality of "Caucaia", Fortaleza, Brazil. They sought to identify the plants most used by the Indians and rescue the culture mischaracterized over the years, of which their therapeutic actions were validated, and their use was ensured by scientific studies. In this study it involved an interview with 45 residents of the indigenous community, including the shaman, applying an interview form to obtain the following information, obtaining socio-economic data, surveys of plants used as medicinal, is identifications of the collected species, reviews in the scientific literature for the species cited. Similarly, there is Lopes 2011 (61) work who surveyed the "Jaguapiru" village, in Dourados in the south of the state of Mato Grosso do Sul, in the second half of 2009. They sought and intended to return to the use, cultivation of medicinal plants, and rescue the traditional knowledge of the use of these plants as an alternative and cultural valorization, in addition to making the children return to valorization the teachings and knowledge of shamans and praying people of the community. In this study they sought the traditional information, and held periodic meetings in the community with students, parents, teachers, with the presence of the chief, the prayers and the patricians will be fundamental to the telling of the stories and myths involving the use of plants about the importance of nature and medicinal plants for the life of traditional peoples. With this study, they intended to sensitize the indigenous community about the traditional wisdom of the use of plants as medicines and valorization of natural medicines, to provide a better knowledge of plants for young people and adolescents of the use of medicinal plants traditionally used by the Guarani Kaiowa peoples existing around the village and thus develop the ability to grow in village backyards. Thus, it is noted that traditional communities have greater baggage on the subject, but suffer constant threat due to the direct influence of modern Western medicine (62).

It is known that the maroons carry with them and still practice the customs of their ancestors among these customs is to practice the use of medicinal plants as an alternative to the cures and treatments of their diseases (63). These same authors promoted research in the quilombo community "Senhor do Bonfim", located in "cepilho" district, July and August 2008, to obtain data such as the diversity of plants in this community, a form of use, partly used, socioeconomic profile of the interviewers. According to the authors, these quilombo populations understand and use medicinal plants, and also have the knowledge for which diseases these herbs can be used. Studies with traditional communities are always valid, Mendieta et al., 2010 (64) elaborated a study in the quilombolas "teixeiras" community, in the municipality of Mostardas, located south of Rio Grande do Sul, during the period from June 2008 to 2009, sought to study and report the medicinal plants used for arterial hypertension by the Quilombola de Mustard community for the treatment of SAH Systemic Arterial Hypertension. A qualitatively based research with the semi-structured interviews, observation of plants with photographic record. Numerous traditional or native societies have vast natural pharmacopeia, good parts from plant resources found in native, cultivated, and/or anthropo-altered environments (65). Rodrigues 2001 (66) conducted a study with rural communities in the southern state of Minas Gerais, microregions of the Upper Rio Grande, where they sought to survey rural communities, rooters and or healers, which, how and for what purposes the native species were used in folk medicine. All the rooters interviewed were descendants of indigenous, African, or both grandparents, and aged between 56-72 years. Among the 13,11 are male and only 2 of them did not constitute a family; the 2 females constituted a family, only 3 transmitted the knowledge about medicinal plants and their use, dosage, and preparation of medicinal plants for some of their children. African slaves brought with them plants that were used for their pharmacological properties and in religious rituals, and these properties were empirically discovered (67). In the constitution of these cultural riches, in addition to traditional communities and "quilombolas", the indigenous peoples stand out, since it is estimated that there are currently about 300,000 Indians throughout the country, employing 170 different native languages. It is also important to highlight that, in our country, 53 indigenous groups still live in isolation from non-Indians (68).

Data collection techniques on medicinal plants: One of the most basic ways of obtaining data in ethnobotanical studies is interviews. These interviews can be divided into four types, structured, unstructured, semi-structured, and informal. About structured interviews, it is a data collection technique that consists of getting the interviewee to answer questions already established by the interviewer. This requires the researcher to take full mastery of the most relevant issues to be explored. Interviews, when not structured or in-depth, cause the interviewer to guide the interview to obey an order in the description of the phenomena of interest to the research (69). According to Posey 1987 (70), a very striking example of this type of interview is the data-generating methodology, which is when the interviewer guides the interview to certain specific questions of interest to the research and may ask the interviewee: tell me about it?. On the other hand, the semistructured interview as the name suggests is a middle ground between the two types mentioned above Structured and unstructured interview, in which the questions are partly formulated by the researcher before going to the field, presenting great flexibility, because it allows deepening elements that may arise during the interview. A tool that is widely used in semi-structured interviews is the questionnaire and that allows the interviewee to fill out his questionnaire (69). These methodologies are continuously used for research when studying the use of medicinal plants by communities. Amorozo 2008 (71) developed a study in the rural community of Vargem Grande, municipality of "Natividade da Serra", São Paulo, during the period from March 2004 to January 2006 and sought to verify the knowledge about the medicinal plants used for the diseases of higher occurrence in the region. Semistructured interviews were conducted to establish the diseases of higher occurrences. As a return for the residents and collaborators, a lecture was presented with the results of the research and elaborated a booklet on the history of the village, research results, and possible care in the administration of medicinal plants. Among the various researches of plant groups, we highlight medicinal plants demanding the need to improve care with collections intended for proper identification (67, 72 - 76). So also, like other studies of Borba 2006 (77) elaborated in the community of "Santa Cruz" neighborhood, in "Chapada dos Guimarães" in Mato Grosso, 
sought to survey the medicinal plants used by the local community, therapeutic indications, preparations and modes of use aimed at the maintenance and recovery of oral health. Through a qualitative approach, using semi-structured interviews, the cataloged species were deposited for identification in the UFMT/Central Herbarium. Questionnaires were applied according to the criteria proposed by Amorozo 1996 (62) and Savastano 1996 (78). With the observation of whether the interviewee lived more than 15 years in the Santa Cruz neighborhood aged over 20 years, they made use/had knowledge of medicinal plants and acquired knowledge informally.

Another type of technique for data collection to be mentioned is the informal interview similar to the unstructured interviews that and when the interviewer guides the interview, but differs from this because it is totally out of the control of the researcher, and it is essential that the interviewer has a field diary so that he can record all the events seen during the research (69). According to Bernard 1988 (79) it is a method that is widely used at first when the interview is taking place and can be developed at all times so that there is an affective bond with the community during the research. This allows the researcher to detect some new facts that will be of relevance to his research. The field journal is used when you record all events that occurred during the working day. Different from the guided tour, which is a method used to work in the field, consisting of supporting and validating the names of the plants mentioned in the interviews. Another method used is the free listing where it aims to seek specific information about the cultural domain of the community studied (69). These methods were used by Giraldi 2010 (44) who developed a study, in the "Sertão of ribeirão", a community of Azorean origin, inserted in the Atlantic forest domain and located within the limits of the Lagoa do Peri Municipal Park PMLP south of the island of Florianópolis - SC, during March 2008 and May 2009. During this period, they sought to make a study on ethnobotany through the use and traditional knowledge of medicinal plants in the "Sertão do Ribeiro". The methodology adopted to obtain the research data were: free listing, semi-structured interview open and closed, tour-guided, photography, collection of botanical material, taxonomic identification, and daily field notes. For Amorozo 2008 (71), there is no contradiction between quantitative and qualitative research, but rather a complementarity between different aspects of the same reality.

\section{METHODOLOGY}

The work consists of the literature review on the theme "Use of medicinal plants sold in Street markets in different regions of Brazil". For this purpose, data were collected in national databases on the use of medicinal plants in Street markets such as SCIELO www.scielo.org, MEDLINE, and LILACS www.bireme.br. Keywords such as medicinal plants, Street markets, markets, plant marketing, ritualistic plants were used. Priorities were given to the works that were easily accessible, articles, and scientific papers were used. The survey of data on medicinal plants used in the Street market in different regions of Brazil was based on 14 scientific articles, were considered articles from 2001 to 2011. The studies were analyzed to provide further clarification on the subject that will investigate which medicinal plants are marketed in different Street markets in Brazil, to inform, therefore, for which therapeutic indications to plants have been most sought after in the Street market in Brazil. The articles where the data were collected are, thus enabling an easy understanding for the survey, the articles analyzed were from the regions of Bahia, Ceará, Mato Grosso do Sul, Minas Gerais, Paraíba, Pará, Pernambuco, Rio de Janeiro. The information of the articles was gathered and compared one by one, all plant names were verified in the 14 articles where the data were collected, first, all articles containing family citation by the informants were considered and gathered correlating to species. The frequencies of the mode of use of medicinal plants and the parts used were verified according to the number of citations of the analyzed articles, the percentages were made through the frequencies of citations. Not all articles had the same information regarding therapeutic indications, some articles did not mention which plants were indicated for that therapy.

\section{RESULTS AND DISCUSSION}

Through a bibliographic survey using the articles of free access, we compared which medicinal plants were most used in Street markets in different regions of Brazil. First, we chose to carry out the research through the articles on the theme "Medicinal plants cited in Street markets of different regions of Brazil" available online looking for the following information in each article analyzed: Botanical families; species; the purpose of the use of the plant food, medicinal and ritualistic bathing; part of the plant used leaf, flower, fruit, seed, bark, root or whole plant; plant habitat tree, subshrub, herbaceous and creeper and finally the number of citations found in the articles with their respective authors, year of study and place of the free fair carried out the research. In the study by Maioli Azevedo 2007 (1) held at the Street markets of Rio de Janeiro in the North and South, the most cited plants were: "chapéu-de-couro", "aroeira", "erva-doce", "oficial-de-sala", "macela", "losna", “alecrim-do-campo", “carqueja”, "picão", "camomila", "girassol", "guaco", "arnica", "boldo", "assapeixe", "carobinha", "sabugueiro", "mastruz" ou "Santa Maria”, “melão-de-são-caetano", “cavalinha”, "pinhão", "quebra-pedra", "poejo", "manjericão", "alfavaca”, "sálvia”, "canela", "louro", "pata-de-vaca", "babosa", "sete-sangrias", "algodão", "vassorinha", "pára-raios", "negra-mina”, "amora”, "espinheira-santa”, “jaborandi”, “transagem”, "lágrima-denossa-senhora", "erva-de-bicho", "unha-de-gato", "arruda, abre-caminho", “jurubeba", “erva-cidreira”, "alfazema”, "insulina", "gengibre" Figure 1 and Table 1. Similar research was also carried out at the Street markets of Paraíba by Souza 2011 (8) in the city of Esperança-PB where the most cited plants were: "aroeira", "erva-doce", "alecrim", "camomila", "boldo", "pau d'arco", "sabugueiro", "sucupira”, "quebrapedra", "canela", "louro", "babosa", "barbatimão", "eucalipto", "romã", "ameixa", “arruda", "erva-cidreira", "papaconha", "gengibre". A research carried out at the Street market of Caruaru Pernambuco by Almeida 2002 (80) the medicinal plants cited were: "aroeira", "erva-doce", "macela", "coco-catolé", "alecrim", “camomila”, "girassol”, "boldo", "pau d'arco", "sabugueiro", "mastruz”, "pau d'arco", "manjericão", “alfavaca”, “canela”, "louro”, "babosa”, "algodão", “angico", “eucalipto", “espinheira-santa”, "jaborandi”, "romã", "arruda", "erva-cidreira", "insulina”, "colônia", "gengibre". In the research of Freire, Santos and Rocha 2009 (81) at the Street Market of Juazeiro do Norte, Ceará only two medicinal plants, "barriguda" and "angico", were compared with the other authors, the plant of the popular name known as "angico", can also be found and cited in the work of Dantas 2008 (82) and Silva 2011 (83) as well as the plant known. 
Table 1. Medicinal plant species cited at Street market in different regions of Brazil, ordered alphabetically from botanical families (Use: Fo - food, Med - medicinal, Rb - ritualistic bath; Part of the plant used: Le - leaf, FI - flower, Fr - fruit, Se - seed, Ba - bark, Rr - root, Pw whole plant; Hab - habit: Arb - arboreal, Sub - subshrub, Her - herbaceous, Cre - creeper; Nc - Number of citations)

\begin{tabular}{|c|c|c|c|c|c|}
\hline Family/Scientific name & Common name & Use & Part used & $\mathrm{Hab}$ & $\mathrm{Nc}$ \\
\hline $\begin{array}{l}\text { ALISMATACEAE } \\
\text { Echinodorus grandiflorus }\end{array}$ & Chapéu-de-couro & $\mathrm{Rb}, \mathrm{Med}$ & $\mathrm{Le}$ & Arb & $\begin{array}{l}\text { (Maioli-Azevedo,2007,zonas Norte e Sul, RJ) } \\
\text { (Lima, Maia e Matos, 2009. Duque de Caxias, RJ) } \\
\text { Nunes et al. 2003. Campo Grande, MS) }\end{array}$ \\
\hline $\begin{array}{l}\text { ANACARDIACEAE } \\
\text { Schinus } \quad \text { terebinthifolius } \\
\text { Raddi. }\end{array}$ & Aroeira & $\mathrm{Rb}$ & Le & Arb & $\begin{array}{l}\text { (Lima, Maia e Matos, 2009, Duque de Caxias, RJ) } \\
\text { (Maioli-Azevedo,2007,zonas Norte e Sul, RJ) } \\
\text { (Almeida e Albuquerque, 2002. Caruaru, PE) } \\
\text { (Alves et al. 2007. Campina Grande, PB) } \\
\text { (Souza, Andrade e Fernandes, 2011. Esperança, PB) } \\
\text { (Silva et al. Jequié, BA) } \\
\text { (Lopes e Lima, 2010. Belém do Pára, PA) } \\
\text { (Ustulin et al.2009, Campo Grande, MS) } \\
\text { (Dantas et al. 2008. Campinas Grande, PB) }\end{array}$ \\
\hline $\begin{array}{l}\text { APIACEAE } \\
\text { Foeniculum vulgare Mill. }\end{array}$ & Erva-doce & Med & Le & Her & $\begin{array}{l}\text { (Maioli-Azevedo,2007,zonas Norte e Sul, RJ) } \\
\text { (Almeida e Albuquerque, 2002. Caruaru, PE) } \\
\text { (Souza, Andrade e Fernandes, 2011. Esperança, PB) } \\
\text { (Parente e Rosa, 2010. Barra do Piraí,RJ) } \\
\text { (Freire, Santos e Ferreira, 2009, Juazeiro do Norte, CE) }\end{array}$ \\
\hline $\begin{array}{l}\text { APOCYNACEAE } \\
\text { Asclepia curassavica L. }\end{array}$ & Oficial-de-sala & $\mathrm{Rb}$ & Pw & Her & $\begin{array}{l}\text { (Maioli-Azevedo,2007,zonas Norte e Sul, RJ) } \\
\text { (Parente e Rosa, 2010. Barra do Piraí,RJ) }\end{array}$ \\
\hline $\begin{array}{l}\text { ASTERACEAE } \\
\text { Achyrocline } \\
\text { (LAM) DC. }\end{array}$ & Macela & Med & $\mathrm{Le}$ & Her & $\begin{array}{l}\text { (Maioli-Azevedo,2007,zonas Norte e Sul, RJ) } \\
\text { (Alves et al. 2007. Campina Grande, PB) } \\
\text { (Almeida e Albuquerque, 2002. Caruaru, PE) } \\
\text { (Nunes et al. 2003. Campo Grande, MS) } \\
\text { (Freire, Santos e Ferreira, 2009, Juazeiro do Norte, CE) } \\
\text { (Dantas et al. 2008. Campinas Grande, PB) }\end{array}$ \\
\hline $\begin{array}{l}\text { ARECACEAE } \\
\text { Syagrus cearensis }\end{array}$ & Coco-catolé & Med & $\mathrm{Pw}$ & Arb & $\begin{array}{l}\text { (Dantas et al. 2008. Campinas Grande, PB) } \\
\text { (Almeida e Albuquerque, 2002. Caruaru, PE) } \\
\text { (Alves et al. 2007. Campina Grande, PB) }\end{array}$ \\
\hline $\begin{array}{l}\text { ARECACEAE } \\
\text { Arthemisia absinthium L. }\end{array}$ & Losna & Med & Le, Fl & Sub & $\begin{array}{l}\text { (Maioli-Azevedo,2007,zonas Norte e Sul, RJ) } \\
\text { (Parente e Rosa, 2010. Barra do Piraí,RJ) } \\
\text { (Dantas et al. 2008. Campinas Grande, PB) }\end{array}$ \\
\hline $\begin{array}{ll}\text { ARECACEAE } & \text { Baccharis } \\
\text { dracuntifolia } \text { DC. } & \end{array}$ & Alecrim-do-campo & Ban, Med & Le, Fl & Sub & $\begin{array}{l}\text { (Maioli-Azevedo,2007,zonas Norte e Sul, RJ)(Lopes e } \\
\text { Lima, 2010. Belém do Pára, PA) (Ustulin et al.2009, } \\
\text { Campo Grande, MS) (Parente e Rosa, 2010. Barra do } \\
\text { Piraí,RJ) }\end{array}$ \\
\hline $\begin{array}{l}\text { LAMIACEAERosmarinus } \\
\text { officinaliis L. }\end{array}$ & Alecrim(alecrim de horta) & Med & Le & Sub & $\begin{array}{l}\text { (Lima, Maia e Matos, 2009. Duque de Caxias, RJ) } \\
\text { (Nunes et al. 2003. Campo Grande, MS) (Almeida e } \\
\text { Albuquerque, 2002. Caruaru, PE) (Souza, Andrade e } \\
\text { Fernandes, 2011. Esperança, PB (Dantas et al. } 2008 . \\
\text { Campinas Grande, PB) }\end{array}$ \\
\hline $\begin{array}{ll}\text { ASTERACEAE } & \text { Baccharis } \\
\text { trimera } \text { DC } & \end{array}$ & Carqueja & Med & $\mathrm{Ba}$ & Her & $\begin{array}{l}\text { (Maioli-Azevedo,2007,zonas Norte e Sul, RJ) (Nunes et } \\
\text { al. 2003. Campo Grande, MS) } \\
\text { (Lima, Maia e Matos, 2009, Duque de Caxias, RJ) } \\
\text { (Parente e Rosa, 2010. Barra do Piraí,RJ) (Ustulin et } \\
\text { al.2009, Campo Grande, MS) (Silva et al. Jequié, BA) }\end{array}$ \\
\hline $\begin{array}{l}\text { ASTERACEAE } \quad \text { Bidens } \\
\text { pilosa } \text { L. }\end{array}$ & Picão (picão roxo) & Med & $\mathrm{Le}$ & Her & $\begin{array}{l}\text { (Maioli-Azevedo,2007,zonas Norte e Sul, RJ) (Parente e } \\
\text { Rosa, 2010. Barra do Piraí, RJ) } \\
\text { (Silva et al. Jequié, BA) }\end{array}$ \\
\hline $\begin{array}{l}\text { ASTERACEAE Coreopsis } \\
\text { grandiflore Hogg ex. Sweet }\end{array}$ & Camomila & Ban,Med & Le & Her & $\begin{array}{l}\text { (Maioli-Azevedo,2007,zonas Norte e Sul, RJ) (Freire, } \\
\text { Santos e Ferreira, 2009, Juazeiro do Norte, CE) }\end{array}$ \\
\hline $\begin{array}{l}\text { ASTERACEAE Matricaria } \\
\text { chamomila L. }\end{array}$ & Camomila & Med & Fl & Her & $\begin{array}{l}\text { (Almeida e Albuquerque, 2002. Caruaru, PE) (Parente e } \\
\text { Rosa, 2010. Barra do Piraí,RJ) } \\
\text { (Lima, Maia e Matos, 2009, Duque de Caxias, RJ) } \\
\text { (Ustulin et al.2009, Campo Grande, MS) ( (Souza, } \\
\text { Andrade e, Fernandes, 2011. Esperança, PB) }\end{array}$ \\
\hline $\begin{array}{l}\text { ASTERACEAE Helianthus } \\
\text { annuus }\end{array}$ & Girassol & Med & $\mathrm{Se}$ & Her & $\begin{array}{l}\text { (Maioli-Azevedo,2007,zonas Norte e Sul, RJ) (Almeida } \\
\text { e Albuquerque, 2002. Caruaru, PE) (Lopes e Lima, } \\
\text { 2010. Belém do Pára, PA) }\end{array}$ \\
\hline $\begin{array}{l}\text { ASTERACEAE Mikania } \\
\text { glomerata }\end{array}$ & Guaco & Med & Fo & Cre & $\begin{array}{l}\text { (Maioli-Azevedo,2007,zonas Norte e Sul, RJ) (Ustulin } \\
\text { et al.2009, Campo Grande, MS) }\end{array}$ \\
\hline $\begin{array}{ll}\text { ASTERACEAE } & \text { Solidago } \\
\text { chilensis } & \end{array}$ & Arnica & Med & Le, Fl & Her & $\begin{array}{l}\text { (Maioli-Azevedo,2007,zonas Norte e Sul, RJ) (Parente e } \\
\text { Rosa, 2010. Barra do Piraí,RJ) } \\
\text { (Alves et al. 2007. Campina Grande, PB) }\end{array}$ \\
\hline $\begin{array}{l}\text { ASTERACEAE Vernonia } \\
\text { condensata }\end{array}$ & Boldo (boldo do Chile) & Med & Le & Her & $\begin{array}{l}\text { (Maioli-Azevedo,2007,zonas Norte e Sul, RJ) (Souza, } \\
\text { Andrade e Fernandes, 2011. Esperança, PB) (Almeida e } \\
\text { Albuquerque, 2002. Caruaru, PE) } \\
\text { (Parente e Rosa, 2010. Barra do Piraí,RJ) (Freire, Santos } \\
\text { e Ferreira, 2009, Juazeiro do Norte, CE) }\end{array}$ \\
\hline $\begin{array}{l}\text { COMPOSITAE Vernonia } \\
\text { scabra }\end{array}$ & Assa-peixe & Rb,Med & Le & Sub & $\begin{array}{l}\text { (Maioli-Azevedo,2007,zonas Norte e Sul, RJ) (Lima, } \\
\text { Maia e Matos, 2009, Duque de Caxias, RJ) }\end{array}$ \\
\hline
\end{tabular}




\begin{tabular}{|c|c|c|c|c|c|}
\hline $\begin{array}{l}\text { BIGNONIACEAE Jacaranda } \\
\text { sp. }\end{array}$ & Carobinha & Med & Le & Arb & $\begin{array}{l}\text { (Maioli-Azevedo,2007,zonas Norte e Sul, RJ) (Parente e } \\
\text { Rosa, 2010. Barra do Piraí, RJ) }\end{array}$ \\
\hline $\begin{array}{l}\text { BIGNONIACEAE } \quad \text { Tabebuia } \\
\text { Impetiginosa }\end{array}$ & Pau'darco ou ipê roxo & Med & $\mathrm{Ba}$ & Arb & $\begin{array}{l}\text { (Alves et al. 2007. Campina Grande, PB) (Almeida e } \\
\text { Albuquerque, 2002. Caruaru, PE) (Souza, Andrade e } \\
\text { Fernandes, 2011. Esperança, PB) (Dantas et al. } 2008 . \\
\text { Campinas Grande, PB) }\end{array}$ \\
\hline $\begin{array}{l}\text { CAPRIFOLIACEAE Sambucus } \\
\text { nigra L. }\end{array}$ & Sabugueiro & $\mathrm{Rb}, \mathrm{Med}$ & Le & Arb & $\begin{array}{l}\text { (Maioli-Azevedo,2007,zonas Norte e Sul, RJ) (Parente e } \\
\text { Rosa, 2010. Barra do Piraí,RJ) (Almeida e Albuquerque, } \\
\text { 2002. Caruaru, PE) (Souza, Andrade e Fernandes, } 2011 . \\
\text { Esperança, PB) Alves et al. 2007. Campina Grande, PB) } \\
\text { (Dantas et al. 2008. Campinas Grande, PB) }\end{array}$ \\
\hline $\begin{array}{l}\text { CAESALPINIACEAE Bauhinia } \\
\text { cheilantha (Bong.) Steud. }\end{array}$ & Mororó & Med & $\mathrm{Le}, \mathrm{Ba}$ & & $\begin{array}{l}\text { (Dantas et al. 2008. Campinas Grande, PB) (Alves et al. } \\
\text { 2007. Campina Grande, PB) }\end{array}$ \\
\hline $\begin{array}{l}\text { CHENOPODIACEAE } \\
\text { Chenopodium ambrosioides L. }\end{array}$ & Mastruz ou santa maria & Med & $\mathrm{Le}$ & Her & $\begin{array}{l}\text { (Maioli-Azevedo,2007,zonas Norte e Sul, RJ) (Parente e } \\
\text { Rosa, 2010. Barra do Piraí,RJ) (Almeida e Albuquerque, } \\
\text { 2002. Caruaru, PE) (Dantas et al. 2008. Campinas } \\
\text { Grande, PB) }\end{array}$ \\
\hline $\begin{array}{l}\text { CUCURBITACEAE } \\
\text { Momordica charantia } \mathrm{L} \text {. }\end{array}$ & Melão-de-são-caetano & Med & Le, Fr & Her & $\begin{array}{l}\text { (Maioli-Azevedo,2007,zonas Norte e Sul, RJ) (Parente e } \\
\text { Rosa, 2010. Barra do Piraí,RJ) (Lima, Maia e Matos, } \\
\text { 2009, Duque de Caxias, RJ) } \\
\text { (Silva et al. Jequié, BA) }\end{array}$ \\
\hline $\begin{array}{l}\text { CUCURBITACEAE L Luffa } \\
\text { operculata }\end{array}$ & Buchinha ou cabacinha & Med & Fr & Her & $\begin{array}{l}\text { (Dantas et al. 2008. Campinas Grande, PB) (Nunes et al. } \\
\text { 2003. Campo Grande, MS) (Lima, Maia e Matos, 2009, } \\
\text { Duque de Caxias, RJ) }\end{array}$ \\
\hline $\begin{array}{l}\text { EQUISETACEAE Equisetum } \\
\text { hyemale L. }\end{array}$ & Cavalinha & Med & $\mathrm{Pw}$ & Her & $\begin{array}{l}\text { (Maioli-Azevedo,2007,zonas Norte e Sul, RJ) (Ustulin } \\
\text { et al.2009, Campo Grande, MS) (Nunes et al. } 2003 . \\
\text { Campo Grande, MS) }\end{array}$ \\
\hline $\begin{array}{l}\text { EUPHORBIACEAE Jatropha } \\
\text { gossypiifolia } \mathrm{L} .\end{array}$ & Pinhão & $\mathrm{Rb}, \mathrm{Med}$ & Le & Her & $\begin{array}{l}\text { (Maioli-Azevedo,2007,zonas Norte e Sul, RJ) (Lopes e } \\
\text { Lima, 2010. Belém do Pára, PA) (Parente e Rosa, } 2010 . \\
\text { Barra do Piraí,RJ) }\end{array}$ \\
\hline $\begin{array}{l}\text { FABACEAE } \quad \text { Bowdichia } \\
\text { virgilioides Kunth. }\end{array}$ & Sucupira & Med & $\mathrm{Se}$ & & $\begin{array}{l}\text { (Souza, Andrade e Fernandes, 2011. Esperança, PB) } \\
\text { (Nunes et al. 2003. Campo Grande, MS) (Lima, Maia e } \\
\text { Matos, 2009, Duque de Caxias, RJ) (Alves et al. } 2007 . \\
\text { Campina Grande, PB) (Dantas et al. 2008. Campinas } \\
\text { Grande, PB) }\end{array}$ \\
\hline $\begin{array}{l}\text { PHYLLANTHUS Phyllanthus } \\
\text { niruri sp. }\end{array}$ & Quebra-pedra & Med & $\mathrm{Le}, \mathrm{Fl}$ & Her & $\begin{array}{l}\text { (Maioli-Azevedo,2007,zonas Norte e Sul, RJ) (Souza, } \\
\text { Andrade e Fernandes, 2011. Esperança, PB) (Alves et } \\
\text { al. 2007. Campina Grande, PB) (Ustulin et al.2009, } \\
\text { Campo Grande, MS) (Almeida e Albuquerque, } 2002 . \\
\text { Caruaru, PE) (Dantas et al. 2008. Campinas Grande, } \\
\text { PB) (Silva et al. Jequié, BA) }\end{array}$ \\
\hline $\begin{array}{l}\text { LAMIACEAE Mentha subg. } \\
\text { Pulegium }\end{array}$ & Poejo & Med & Le & Her & $\begin{array}{l}\text { (Maioli-Azevedo,2007,zonas Norte e Sul, RJ) (Parente e } \\
\text { Rosa, 2010. Barra do Piraí,RJ) }\end{array}$ \\
\hline $\begin{array}{l}\text { LAMIACEAE } \quad \text { Ocimum } \\
\text { basilicum }\end{array}$ & Manjericão & $\mathrm{Rb}, \mathrm{Med}$ & Le & Her & $\begin{array}{l}\text { (Maioli-Azevedo,2007,zonas Norte e Sul, RJ) (Ustulin } \\
\text { et al.2009, Campo Grande, MS) (Lima, Maia e Matos, } \\
\text { 2009, Duque de Caxias, RJ) (Parente e Rosa, } 2010 . \\
\text { Barra do Piraí,RJ) (Almeida e Albuquerque, } 2002 . \\
\text { Caruaru, PE) }\end{array}$ \\
\hline Ocimum & Alfavaca & $\mathrm{Rb}, \mathrm{Med}$ & Le, Fl & Sub & $\begin{array}{l}\text { (Maioli-Azevedo,2007,zonas Norte e Sul, RJ) (Lopes e } \\
\text { Lima, 2010. Belém do Pára, PA) (Parente e Rosa, } 2010 . \\
\text { Barra do Piraí,RJ) (Almeida e Albuquerque, } 2002 . \\
\text { Caruaru, PE) (Silva et al. Jequié, BA) (Ustulin et } \\
\text { al.2009, Campo Grande, MS) }\end{array}$ \\
\hline LAMIACEAE Salvia officinalis & Sálvia & $\mathrm{Al}, \mathrm{Rb}$ & $\mathrm{Le}$ & Sub & $\begin{array}{l}\text { (Maioli-Azevedo,2007,zonas Norte e Sul, RJ) (Parente e } \\
\text { Rosa, 2010. Barra do Piraí,RJ) }\end{array}$ \\
\hline $\begin{array}{l}\text { LAURACEAE Cinnamomum } \\
\text { zeylanicum }\end{array}$ & Canela & Ban, Med & $\mathrm{Le}, \mathrm{Ba}$ & Arb & $\begin{array}{l}\text { (Maioli-Azevedo,2007,zonas Norte e Sul, RJ) (Souza, } \\
\text { Andrade e Fernandes, 2011. Esperança, PB) (Almeida e } \\
\text { Albuquerque, 2002. Caruaru, PE) }\end{array}$ \\
\hline LAURACEAE Laurus nobilis L. & Louro & $\mathrm{Al}$ & Le & Arb & $\begin{array}{l}\text { (Maioli-Azevedo,2007,zonas Norte e Sul, RJ) (Souza, } \\
\text { Andrade e Fernandes, 2011. Esperança, PB) (Lima, } \\
\text { Maia e Matos, 2009, Duque de Caxias, RJ) (Almeida e } \\
\text { Albuquerque, 2002. Caruaru, PE) }\end{array}$ \\
\hline $\begin{array}{l}\text { LEGUMINOSA Bauhinia } \\
\text { forficata }\end{array}$ & Pata-de-vaca & Med & Le & Her & $\begin{array}{l}\text { (Maioli-Azevedo,2007,zonas Norte e Sul, RJ) (Parente e } \\
\text { Rosa, 2010. Barra do Piraí,RJ) (Silva et al. Jequié, BA) }\end{array}$ \\
\hline $\begin{array}{l}\text { LILIACEAE Aloe arborescens } \\
\text { Mill. }\end{array}$ & Babosa & Med & Le & Her & $\begin{array}{l}\text { (Maioli-Azevedo,2007,zonas Norte e Sul, RJ) (Souza, } \\
\text { Andrade e Fernandes, 2011. Esperança, PB) (Lopes e } \\
\text { Lima, 2010. Belém do Pára, PA) (Parente e Rosa, } 2010 . \\
\text { Barra do Piraí,RJ) (Almeida e Albuquerque, } 2002 . \\
\text { Caruaru, PE) (Dantas et al. 2008. Campinas Grande, } \\
\text { PB) }\end{array}$ \\
\hline $\begin{array}{l}\text { LYTRACEAE } \quad \text { Cuphea } \\
\text { carthagenesis (Jacq.) J.F.Macbr. }\end{array}$ & Sete-sangria & Med & Le & Her & $\begin{array}{l}\text { (Maioli-Azevedo,2007,zonas Norte e Sul, RJ) (Parente e } \\
\text { Rosa, 2010. Barra do Piraí,RJ) (Nunes et al. } 2003 . \\
\text { Campo Grande, MS) (Silva et al. Jequié, BA) }\end{array}$ \\
\hline $\begin{array}{l}\text { MALVACEAE } \\
\text { barbadense L. }\end{array}$ & Algodão & $\mathrm{Rb}, \mathrm{Med}$ & Le & Arb & $\begin{array}{l}\text { (Maioli-Azevedo,2007,zonas Norte e Sul, RJ) (Ustulin } \\
\text { et al.2009, Campo Grande, MS) (Parente e Rosa, } 2010 . \\
\text { Barra do Piraí,RJ) (Almeida e Albuquerque, } 2002 . \\
\text { Caruaru, PE) (Silva et al. Jequié, BA) }\end{array}$ \\
\hline
\end{tabular}




\begin{tabular}{|c|c|c|c|c|c|}
\hline $\begin{array}{l}\text { MALVACEAE Sida panicautis } \\
\text { Cav. }\end{array}$ & Vassorinha & Med & Le & Sub & $\begin{array}{l}\text { (Maioli-Azevedo,2007,zonas Norte e Sul, RJ) (Ustulin et } \\
\text { al.2009, Campo Grande, MS) }\end{array}$ \\
\hline MALVACEAE Ceiba glaziovii & Barriguda & Med & Le & & $\begin{array}{l}\text { (Dantas et al. 2008. Campinas Grande, PB) } \\
\text { (Macedo, Santos e Rocha, 2009. Juazeiro do Norte, CE) }\end{array}$ \\
\hline $\begin{array}{l}\text { MELIACEAE Melia azedarach } \\
\text { L. }\end{array}$ & Pára-raio & $\mathrm{Rb}$ & $\mathrm{Pw}$ & Arb & $\begin{array}{l}\text { (Maioli-Azevedo,2007,zonas Norte e Sul, RJ) } \\
\text { (Parente e Rosa, 2010. Barra do Piraí,RJ) }\end{array}$ \\
\hline $\begin{array}{l}\text { MIMOSACEAE } \\
\text { Stryphnodendron adstringens }\end{array}$ & Barbatimão & Med & $\mathrm{Ba}, \mathrm{Le}$ & & $\begin{array}{l}\text { (Alves et al. 2007. Campina Grande, PB) (Souza, Andrade e } \\
\text { Fernandes, 2011. Esperança, PB) (Lima, Maia e Matos, 2009, } \\
\text { Duque de Caxias, RJ) } \\
\text { (Ustulin et al.2009, Campo Grande, MS) (Nunes et al. } 2003 . \\
\text { Campo Grande, MS) (Silva et al. Jequié, BA) }\end{array}$ \\
\hline $\begin{array}{l}\text { FABACEAE Anadenanthera } \\
\text { colubrina }\end{array}$ & Angico & Med & $\mathrm{Se}$ & Arb & $\begin{array}{l}\text { (Dantas et al. 2008. Campinas Grande, PB) (Al Almeida e } \\
\text { Albuquerque, 2002. Caruaru, PE); (Silva et al. Jequié, BA) } \\
\text { (Macedo, Santos e Rocha, 2009. Juazeiro do Norte, CE) }\end{array}$ \\
\hline MYRTACEAE Eucalyptus sp. & Eucalipto & Med & Le & & $\begin{array}{l}\text { (Alves et al. 2007. Campina Grande, PB) (Souza, Andrade e } \\
\text { Fernandes, 2011. Esperança, PB) (Dantas et al. } 2008 . \\
\text { Campinas Grande, PB) (Almeida e Albuquerque, } 2002 . \\
\text { Caruaru, PE) }\end{array}$ \\
\hline $\begin{array}{l}\text { MONIMIACEAE Siparuna } \\
\text { guianensis Aubl. }\end{array}$ & Negra-mina & $\mathrm{Rb}$ & Le, Fl, Fr & Arb & $\begin{array}{l}\text { (Maioli-Azevedo,2007,zonas Norte e Sul, RJ) (Parente e Rosa, } \\
\text { 2010. Barra do Piraí,RJ) }\end{array}$ \\
\hline $\begin{array}{l}\text { MORACEAE } \quad \text { Sorocea } \\
\text { guilleminiana }\end{array}$ & Espinheira-santa & Med & Le & Arb & $\begin{array}{l}\text { (Maioli-Azevedo,2007,zonas Norte e Sul, RJ) (Lima, Maia e } \\
\text { Matos, 2009, Duque de Caxias, RJ) (Parente e Rosa, } 2010 . \\
\text { Barra do Piraí,RJ) (Almeida e Albuquerque, 2002. Caruaru, } \\
\text { PE) (Nunes et al. 2003. Campo Grande, MS) (Silva et al. } \\
\text { Jequié, BA) }\end{array}$ \\
\hline $\begin{array}{l}\text { PHYTOLACACEAE Petiveria } \\
\text { alliacea } \mathrm{L} \text {. }\end{array}$ & Guiné-piu-piu & $\mathrm{Rb}, \mathrm{Med}$ & Le & Sub & $\begin{array}{l}\text { (Alves et al. 2007. Campina Grande, PB) (Parente e Rosa, } \\
\text { 2010. Barra do Piraí,RJ) }\end{array}$ \\
\hline $\begin{array}{l}\text { PIPERACEAE } \quad \text { hoffmann } \\
\text { seggianum }\end{array}$ & Jaborandi & Med & Le & Arb & $\begin{array}{l}\text { (Maioli-Azevedo,2007,zonas Norte e Sul, RJ) (Almeida e } \\
\text { Albuquerque, 2002. Caruaru, PE) }\end{array}$ \\
\hline $\begin{array}{l}\text { PLANTAGINACEAE Plantago } \\
\text { major } \text { L. }\end{array}$ & Transagem & Med & Le & Her & $\begin{array}{l}\text { (Maioli-Azevedo,2007,zonas Norte e Sul, RJ) (Lima, Maia e } \\
\text { Matos, 2009, Duque de Caxias, RJ) (Nunes et al. } 2003 . \\
\text { Campo Grande, MS) } \\
\text { (Parente e Rosa, 2010. Barra do Piraí,RJ) }\end{array}$ \\
\hline POACEAE Coix lacrima-jobi L. & $\begin{array}{l}\text { Lágima-de-nossa- } \\
\text { senhora }\end{array}$ & $\mathrm{Rb}, \mathrm{Med}$ & Le & Her & $\begin{array}{l}\text { (Maioli-Azevedo,2007,zonas Norte e Sul, RJ) (Parente e Rosa, } \\
\text { 2010. Barra do Piraí,RJ) }\end{array}$ \\
\hline $\begin{array}{l}\text { POLYGONACEAE Polygon } \\
\text { spectabilis L. }\end{array}$ & Erva-de-bicho & Med & Le & Her & $\begin{array}{l}\text { (Maioli-Azevedo,2007,zonas Norte e Sul, RJ (Lima, Maia e } \\
\text { Matos, 2009, Duque de Caxias, RJ) (Nunes et al. } 2003 . \\
\text { Campo Grande, MS) }\end{array}$ \\
\hline $\begin{array}{l}\text { PUNICACEAE } \\
\text { granatum } \mathrm{L} .\end{array}$ & Romã & Med & Le, Fr & Arb & $\begin{array}{l}\text { (Lopes e Lima, 2010. Belém do Pára, PA) (Souza, Andrade e } \\
\text { Fernandes, 2011. Esperança, PB) (Almeida e Albuquerque, } \\
\text { 2002. Caruaru, PE) (Dantas et al. 2008. Campinas Grande, } \\
\text { PB) }\end{array}$ \\
\hline $\begin{array}{l}\text { ROSACEAE } \quad \text { Ximenia } \\
\text { americana } \mathrm{L} .\end{array}$ & Ameixa & Med & $\mathrm{Ba}$ & & $\begin{array}{l}\text { (Alves et al. 2007. Campina Grande, PB) (Souza, Andrade e } \\
\text { Fernandes, 2011. Esperança, PB) (Dantas et al. } 2008 . \\
\text { Campinas Grande, PB) }\end{array}$ \\
\hline BIACEAE Uncaria tomentosa & Unha-de-gato & Med & Le, Fl, Ro & Her & $\begin{array}{l}\text { (Maioli-Azevedo,2007,zonas Norte e Sul, RJ) (Lima, Maia e } \\
\text { Matos, 2009, Duque de Caxias, RJ) (Dantas et al. } 2008 . \\
\text { Campinas Grande, PB) }\end{array}$ \\
\hline $\begin{array}{c}\text { RUTACEAE } \\
\text { Ruta graveolens L }\end{array}$ & Arruda & $\mathrm{Rb}, \mathrm{Med}$ & Pw, Le & Her & $\begin{array}{l}\text { (Maioli-Azevedo,2007,zonas Norte e Sul, RJ) (Lopes e Lima, } \\
\text { 2010. Belém do Pára, PA) (Souza, Andrade e Fernandes, } \\
\text { 2011. Esperança, PB) (Lima, Maia e Matos, 2009, Duque de } \\
\text { Caxias, RJ) (Almeida e Albuquerque, 2002. Caruaru, PE) } \\
\text { (Dantas et al. 2008. Campinas Grande, PB) }\end{array}$ \\
\hline ACEAE Sideroxylon obtusifolium & Quixaba & Med & $\mathrm{Ba}$ & & $\begin{array}{l}\text { (Dantas et al. 2008. Campinas Grande, PB) (Alves et al. } 2007 . \\
\text { Campina Grande, PB) }\end{array}$ \\
\hline $\begin{array}{l}\text { IZEAECEAE Lygodium volubile } \\
\text { Sw. }\end{array}$ & Abre-caminho & $\mathrm{Rb}$ & Le & Arb & $\begin{array}{l}\text { (Maioli-Azevedo,2007,zonas Norte e Sul, RJ) (Parente e Rosa, } \\
\text { 2010. Barra do Piraí,RJ) }\end{array}$ \\
\hline ANACEAE S. paniculatum L. & Jurubeba & Med & Le, Fl & Arb & $\begin{array}{l}\text { (Maioli-Azevedo,2007,zonas Norte e Sul, RJ) (Parente e Rosa, } \\
\text { 2010. Barra do Piraí,RJ) (Dantas et al. 2008. Campinas } \\
\text { Grande, PB) }\end{array}$ \\
\hline RTICACEAE Urera mitis L. & Urtiga-branca & $\mathrm{Rb}, \mathrm{Med}$ & Le, Fl & Her & $\begin{array}{l}\text { (Alves et al. 2007. Campina Grande, PB) (Dantas et al. } 2008 . \\
\text { Campinas Grande, PB) }\end{array}$ \\
\hline ERBENACEAE Lippia alba & Erva-cidreira & $\mathrm{Rb}, \mathrm{Med}$ & Le & Her & $\begin{array}{l}\text {-Azevedo,2007,zonas Norte e Sul, RJ) (Lopes e Lima, } 2010 . \\
\text { Belém do Pára, PA) (Almeida e Albuquerque, 2002. Caruaru, } \\
\text { PE) (Parente e Rosa, 2010. Barra do Piraí,RJ) (Souza, } \\
\text { Andrade e Fernandes, 2011. Esperança, PB) }\end{array}$ \\
\hline $\begin{array}{c}\text { ALFAZEMA Lavandula } \\
\text { latifólia (L.) } \\
\end{array}$ & Alfazema & $\mathrm{Rb}$ & Le & Her & $\begin{array}{l}\text {-Azevedo,2007,zonas Norte e Sul, RJ) (Lopes e Lima, } 2010 . \\
\text { Belém do Pára, PA) (Parente e Rosa, 2010. Barra do Piraí,RJ) } \\
\end{array}$ \\
\hline ACEAE Cissus verticillata (L.) & Insulina & Med & Le & Cre & $\begin{array}{l}\text {-Azevedo,2007,zonas Norte e Sul, RJ) (Almeida e } \\
\text { puquerque, 2002. Caruaru, PE) }\end{array}$ \\
\hline $\begin{array}{l}\text { ACEAE Hibanthus ipecacuanha } \\
\text { (L.) }\end{array}$ & Papaconha & Med & Ro & & $\begin{array}{l}\text { et al. 2008. Campinas Grande, PB) (Souza, Andrade e } \\
\text { nandes, 2011. Esperança, PB) (Alves et al. 2007. Campina } \\
\text { ande, PB) }\end{array}$ \\
\hline IBERACEAE Alpinia zerumbet & Colônia & $\mathrm{Rb}$ & $\mathrm{Le}$ & Her & $\begin{array}{l}\text { e Lima, 2010. Belém do Pára, PA) (Alves et al. 2007. Campina } \\
\text { Grande, PB) (Almeida e Albuquerque, 2002. Caruaru, PE) }\end{array}$ \\
\hline $\begin{array}{l}\text { ZINGIBERACEAE Zingiber } \\
\text { officinale }\end{array}$ & Gengibre & Med & Ro & Her & $\begin{array}{l}\text {-Azevedo,2007,zonas Norte e Sul, RJ) (Souza, Andrade e } \\
\text { Fernandes, 2011. Esperança, PB) (Almeida e Albuquerque, } \\
\text { 2002. Caruaru, PE) (Dantas et al. 2008. Campinas Grande, } \\
\text { PB) }\end{array}$ \\
\hline
\end{tabular}


Alves et al. 2007 (84) conducted a survey in markets and street markets in the city of Campina Grande, Paraíba, the most cited are: "aroeira", "macela", “coco - catolé", "arnica", "ipê roxo", "sabugueiro", "mororó", "sucupira", "quebra-pedra", "barbatimão", “eucalipto”, "guiné ou tipi”, “ameixa, quixaba”, "urtiga-branca", "papaconha", "colônia". In Juazeiro do Norte Ceará in Freire 2009 (85) conducted a study at the Street market where the sellers of medicinal herbs are descendants of the racial mixture of indigenous, black and white elements, the medicinal plants are: "macela", "boldo", "camomila" e "ervadoce". Data different from the common names of medicinal plants can be verified by Silva 2011 (83) who did an investigation on the diversity of plant resources marketed in a Street market, in the municipality of Jequié, Bahia, the medicinal plants cited are: "aroeira", "carqueja", "picão roxo", "melão-de-são-caetano", "quebra-pedra", "pata-de-vaca", "sete-sangrias", "barbatimão", "algodão-do-campo". Although these studies deal with the northeast region, it is still noted that the differences in the custom of popular use of plants, since the citations of plants in the fairs of these states, Paraíba, Ceará, and Bahia were different. In the North region was found a study conducted in "Ver-o-Peso", Belém, State of Pará, known for a place of possible preservation and dissemination of cultural practices and beliefs of African origin, where the use of medicinal plants sold in this free fair is both for therapeutiurposes and for ritualistic baths, being this practice of greater demand in this region. The medicinal plants cited were: "aroeira", "alecrim de angola", "girassol", "pinhão roxo", "alfavaca", "babosa", "romã", "arruda", "erva-cidreira", "alfazema”, "colônia" (86). In Mato Grosso, Ustulin 2009 (87) conducted a research in a municipal market in Campo Grande with the intention of preparing an ethnopharmacological survey of the main plant species marketed in the market. From the results found, the plants were: "aroeira", "erva cidreira-dearbusto", "carqueja”, "camomila", "guaco", "cavalinha”, "quebra-pedra", "manjericão-cheiroso", "alfavaca", "algodão", "vassorinha", "barbatimão", "amora".

In the same state, another study was conducted by Nunes et al. 2003 (88) on the survey of medicinal plants most requested by rooters in the center of Campo Grande Mato Grosso do Sul in which they were mentioned were: "carqueja", "barbatimão", "sete-sangrias", "sucupira", "cavalinha", "chapéu-de-couro", "macela", "buchinha", "alecrim", "espinheira-santa", "transagem". Dantas 2008 (82) interviewed the rooters who sold plants and bottles at fairs, and markets in the city of Campina Grande - PB, where the most used plants are: "aroeira", "macela", "coco - catolé", "losna", "alecrim", "ipê roxo", "sabugueiro", "mororó”, "mastruz", “cabacinha”, "sucupira", "quebra-pedra", "angico", “eucalipto", "romã”, "ameixa”, "arruda”, "quixabeira”, "jurubeba”, "urtiga-branca”, "ipepaconha", "gengibre”, "babosa", "barriguda", "unha-degato". In Duque de Caxias in Rio de Janeiro, Lima 2009 (89) also surveyed medicinal plants marketed at the Street market of the municipality, the plants were: "chapéu-de-couro", "aroeira", "alecrim", "carqueja", "camomila", "assa-peixe", "melão-de-são-caetano", "buchinha do norte", "sucupira”, "manjericão", "louro", "barbatimão", "espinheia-santa", "tanchagem", "erva-de-bicho", "unha-de-gato", "arruda". The municipality of Barra do Pirai, Rio de Janeiro, was also conducted a research where Parente 2001 (14) verified through interviews with erveiro in the only free fair of the municipality, which medicinal plants most commercialized on site, the plants mentioned were: "erva-doce", "oficial-de-sala", "losna", "alecrim-do-campo", "arnica", "boldo-do-Chile", “carobinha”, “sabugueiro", “santa Maria”, “melão-de-sãocaetano", "pinhão", "poejo", “manjericão", "alfavaca", "sálvia", "pata-de-vaca", "babosa sete-sangrias", "algodão", "pára-raio", "negra-mina", “espinheira-santa", "guiné”, "tanchagem", "lágrima-de-nossa-senhora", "abre-caminho", "jurubeba", "erva-cidreira", "alfazema". As each region has its popular way of expressing itself, some differences in the name of medicinal plants were observed, such as "alecrim" that and called "alecim-do-campo" in the North and South of Rio de Janeiro according to Maioli-Azevedo 2007 (1), already in Belém do Pará in the "Ver-o-peso" it's called "alecrim de Angola" besides being used as a medicinal is also widely used for ritualistic baths and smoking, a way widely used by the local population that follows ancient practices and cultures (86). In Campo Grande, MS, there are two popular modes in the region of being called and can be: "alecrim-do-campo" or "erva-cidreira-de-arbusto" (87). In Campo Grande, Mato Grosso do Sul, when conducting a research Nunes 2003 (88) understood that the species Luffa operaculata is popularly known as: "buchinha" in this region, unlike what happens with this same species in Duque de Caxias, Rio de Janeiro, known as "bucinha-do-Norte" (89).

According to Dantas 2008 (82) in Campina Grande, Paraíba, this same species is popularly known in the region as: "cabacinha", you can then notice that for each region there is a particular way of calling for each medicinal plant, which is confirmed even in the municipality itself where there are differences regarding popular names, as in Campina Grande, Paraíba, the same plant there are two or Mayan variations of names (84). Maioli Azevedo 2007 (1), reported that the "picão" does not change its name in the region, but already in Jequié, Bahia, it is called: "picão-roxo" (83). Thus, noting that there is a small difference in the name, a form of adaptation that can say so, for each region. According to Valentini 2009 (90) the use of "negramina" Siparune guianensis Aublet in "Varzea Grande" - MT, is indicated for ritualistic baths as well as for medicinal use such as influenza relief, fever, and body pain, the form of preparation and decoction. Already in "Barra do Pirai" in Rio de Janeiro this same species changes a small detail in the popular name being taken the letter " $r$ " of the name being thus "negamina" and only has the use for ritualistic bathing according to Parente 2010 (14). For example, in the popular name being taken the letter " $r$ " of the name thus being negamina and only has the use for ritualistic bathing according to Parente 2010 (14), some plants mentioned can be observed in Table 1 .

We surveyed the therapeutic indications that had a higher number of citations were stomach diseases with 17 citations and 13 number of species cited for this therapeutic indication, flu-like symptoms 14 citations for 9 plants cited; skin problems and healing 13 citations for 10 species cited; ritual baths 12 citations for 12 species cited; anti-inflammatory and diuretic sours had 11 citations and number of species cited were 6 species 10, respectively. For tranquilizers and treatment of low back pain, they had 10 citations, where the number of $p$ species were 6 and 7, respectively, as can be seen in Figure 1. The most used parts of medicinal plants in the free fairs were leaves with $60.1 \%$, a flower with $13.5 \%$, bark with $9.0 \%$ and fruit $7.7 \%$, these data can be seen in Figure 3 below: As for the most used mode of medicinal plants purchased at free fairs in Brazil were $71 \%$ of medicinal use, $27 \%$ as ritualistic baths and $2 \%$ as food use. It can be seen in Figure 4. 


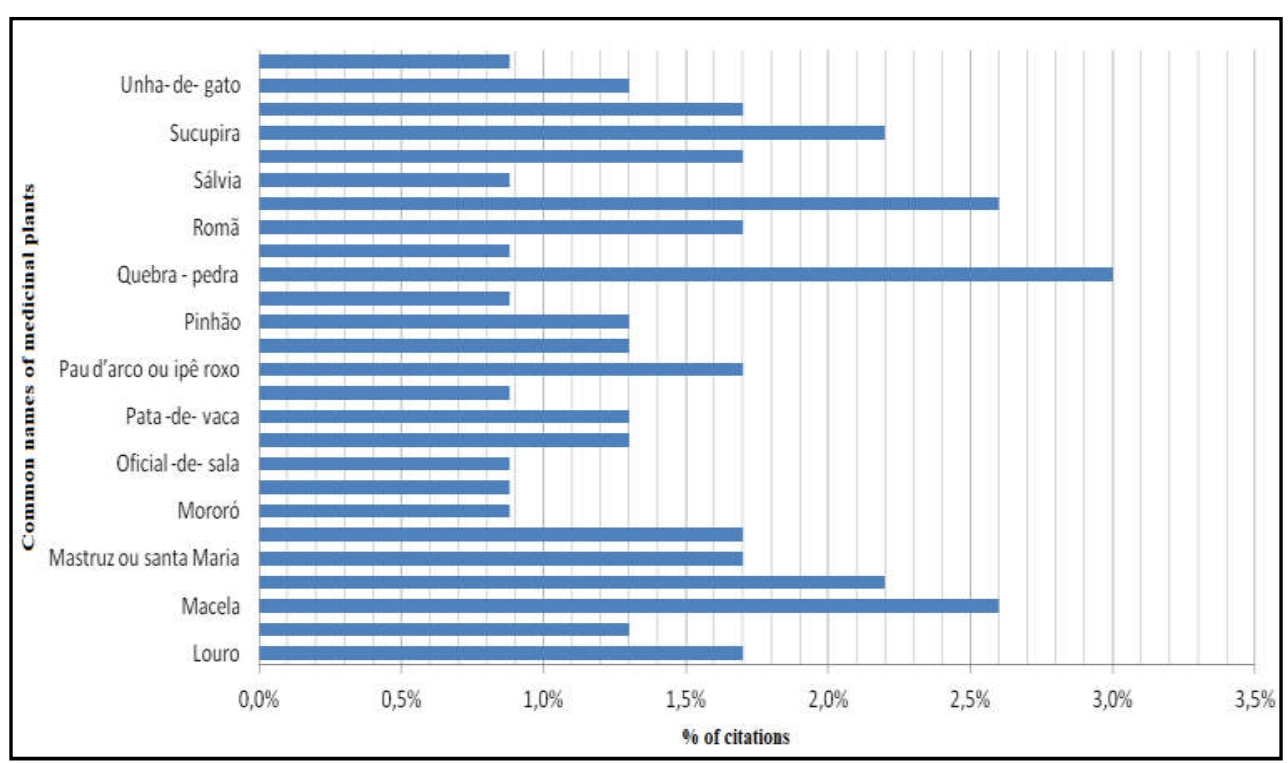

Figure 1. Common names of medicinal plants found in the different Street market in Brazil.

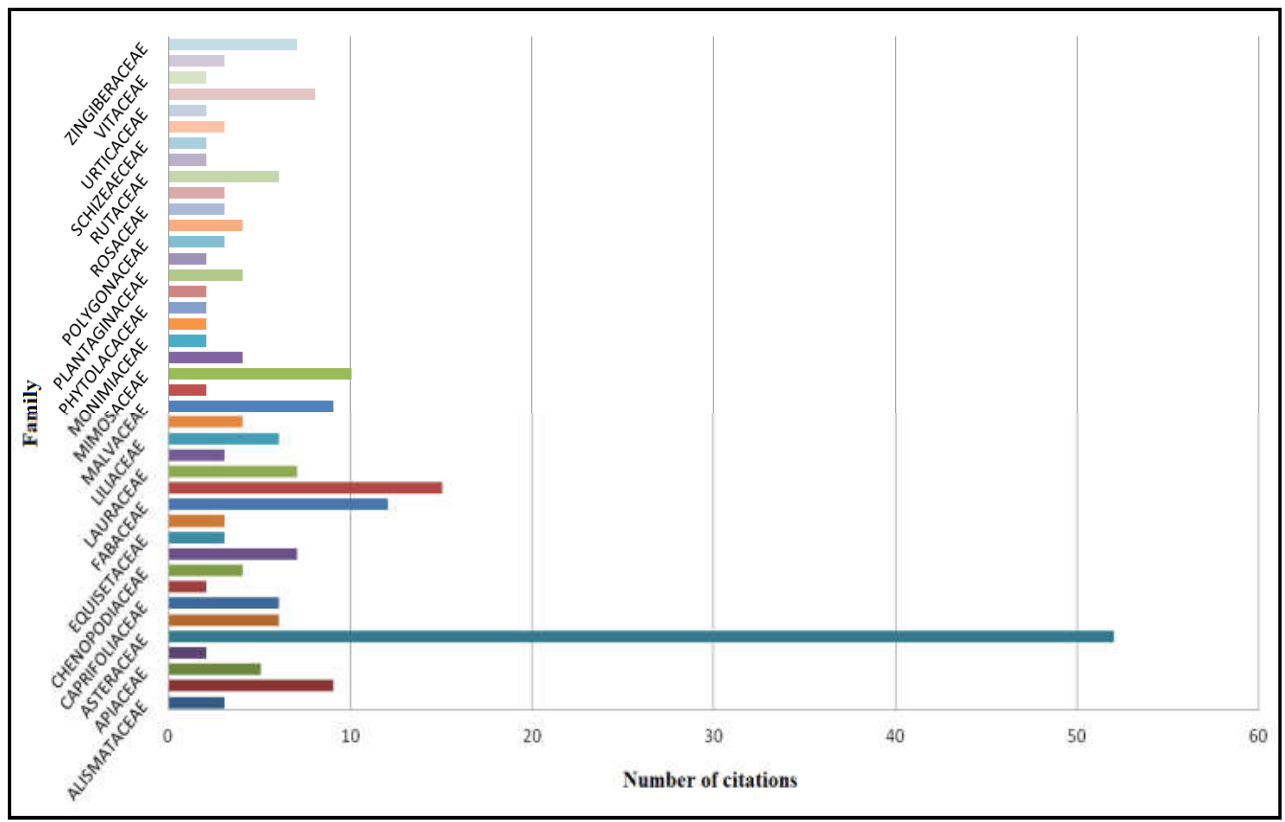

Figure 2. Family of medicinal plants marketed in the Street market of different regions of Brazil with their respective numbers of citations per species.

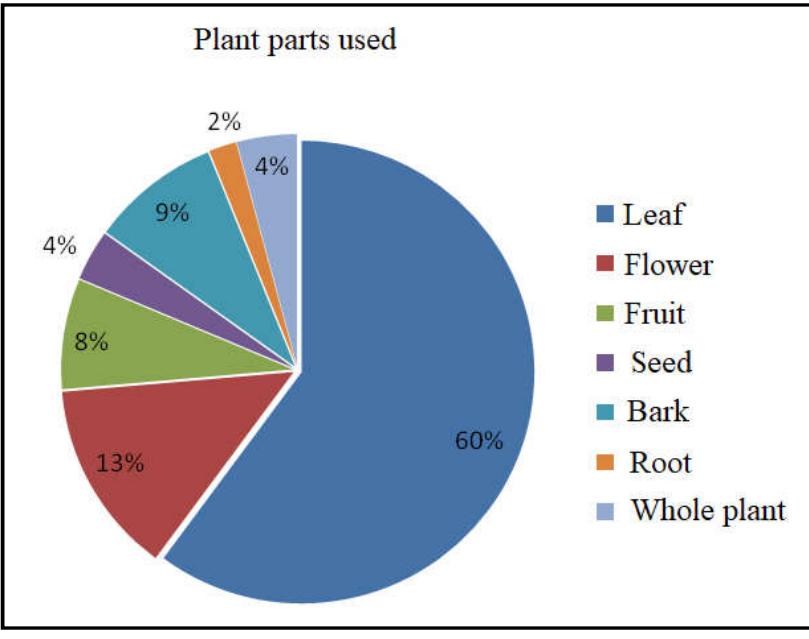

Figure 3. Parts of medicinal plants marketed in the Street market in Brazil

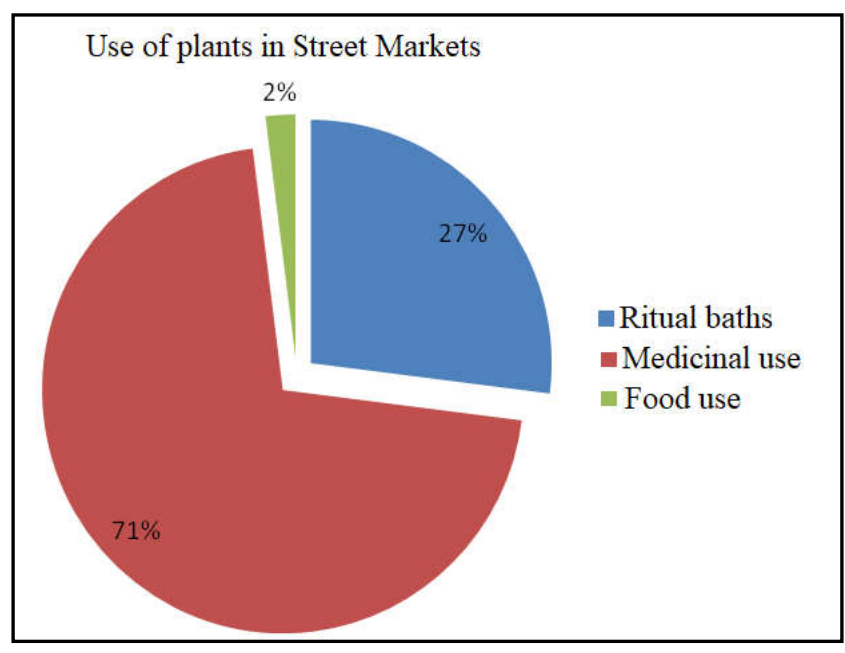

Figure 4: Use of medicinal plants in the Street Market in Brazil 


\section{Final considerations}

Popular knowledge about the use of medicinal plants has been passed down from generation to generation, the use of home remedies has been going through generations over many years. As Brazil and rich in diversity and natural resources then make it possible that this knowledge about medicinal plants is passed on to other generations. Because it is an easily accessible and economically accessible practice, its treatment has fewer side effects, being a natural mode of treatment. However, it should be noted that overuse can also cause side effects even though it is natural medicines, as every incorrectly used drug can have its side effects. For some therapeutic indications and advisable to seek help from a specialized professional to make a correct indication and dosage of the drug, whether coming from a drugstore or an herb acquired from a Street market stall that is easily found in several different regions of Brazil, the free fairs are places where you find a variety of medicinal herbs and wisdom passed down from generation to generation, the herb sellers are good connoisseurs of this ancient practice. Finally, it is worth mentioning that the result obtained through bibliographic surveys on the use of medicinal plants in free fairs in different regions of Brazil and ancient practice is even over the years this practice remains very strong in several regions of Brazil. It is also worth mentioning that these herbs are no longer found only in free fairs and also beginning to be found in the Sreet market, it is concluded that then and of paramount importance for the financial market.

\section{REFERENCES}

[1] Maioli-azevedo V, Fonseca-kruel VS. 2007. Plantas medicinais e ritualísticas vendidas em feiras livres no município do Rio de Janeiro, RJ, Brasil. Acta Botanica Brasílica, v.21, n.2, p.263-275.

[2] Martins ER, Castro DM, CastellaniD. 1994. Plantas Medicinais: Outras Plantas Popularmente Utilizadas.19 ed. Viçosa: ImprenssaUnversitária, v.1, p.305.

[3] Alexandre RF, Bagatini F, Simões CMO. 2008. Interações entre fármacos e medicamentos fitoterápicos á base de ginkgo ou ginseng. Revista Brasileira de Farmacognosia, Florianópolis-SC, v.18, n. 1, p. 117-126.

[4] Brasil MDS, "Ministério Da Saúde". 2006. Secretaria de Ciência, Tecnologia e Insumos Estratégicos. Departamento de Assistência Farmacêutica. A fitoterapia no SUS e o Programa de Pesquisas de Plantas Medicinais da Central de Medicamentos. Brasília, DF.

[5] Brasil MDS, "Ministério Da Saúde". 2007. Secretária de Ciência, Tecnologia e Insumos Estratégicos. Programa Nacional de Plantas Medicinais e Fitoterápicos. Brasília, Ministério da Saúde.

[6] Martin GJ. 1995. Ethnobotany - A method manual. New York, Chapman \& Hall.

[7] Dorigoni PA, Ghendini PC, Fróes LF, Baptista KC, Ethur ABM, Baldisserotto B, Buger ME, Almeida CE, Lopes AMV, Záchia RA 2001. Levantamentos de dados sobre plantas medicinais de uso popular no município de São João do Polêsine, RS, Brasil. I- Relação entre enfermidades e espécies utilizadas.Revista Brasileira de plantas medicinais, v.4, n.1, p. 69-79.

[8] Souza MZS, Andrade MSM, Fernades MSM 2011. Levantamento sobre plantas medicinais comercializadas na feira livre da cidade de Esperança-PB. BIOFAR: revista de biologia de farmácia, p.1983-4209, v.05, n.01.
[9] Fitomedicina popular. 2009. Medicina popular. Disponível em: <http://fitomedicinapopular.>. Acesso em: 21-05-2011.

[10] França ISX, Souza JA, Baptista R, Britto VRS 2008. Medicina popular: benefícios e maléficos das plantas medicinais. Revista Brasílica de Enfermagem, v.61, n.2, p.201-208.

[11] Rezende HA, Cocco MIM. 2002. A utilização de fitoterápico no cotidiano de uma população rural. RevEscEnferm USP, v.36, n.3, p.282-288, São Paulo.

[12] Borges LA. 2010. Levantamento etnofarmacológico do uso de Lychnophoraericoides recurso terapêutico. 52.f. Trabalho de Conclusão de Curso Farmácia - Centro Universitário Unirg.

[13] Almeida MZ. 2003. Plantas medicinais. 2.ed. Salvador, EDUFBA.

[14] Parente CET, Rosa MMT 2001. Plantas comercializadas como medicinal no Município de Barra do Piraí, RJ. Rodriguésia, v. 52, n.80, p.47-59.

[15] IUCNR "The International Union for Conservation of Nature and Natural Resources. 1993. Guidelines on the conservation of medicinal plants. Gland: Switzerland, p.50, 1993.

[16] Diegues ACSO. 1998. Mito Moderno da Natureza Intocada. Editora HUCITEC. São Paulo.

[17] Vale, NB. 2002. A farmacobotânica, ainda tem lugar na moderna anestesiologia? Revista Brasileira Anestesiologia, v. 52, n.3, p.368-80

[18] Lainetti R, Brito ERS. 1980. A saúde pelas plantas e ervas do mundo inteiro. Rio de Janeiro. Ediouro.

[19] Matos FJA. 1999. Plantas da medicina popular do Nordeste: propriedades atribuídas e confirmadas. Fortaleza. UFC.

[20] Badke AR, Budó MLD, Silva FM, Ressel LB. 2011. Plantas medicinais: o saber sustentado na prática do cotidiano popular. Esc. Anna Nery. Rio de Janeiro, v.15, n.1.

[21] Hamilton AC. 2004. Medicinal plants, conservation, and livelihoods. Biodiversity and conservation, v.13, s.n, p.1477-1517.

[22] Lorenzi H, Matos FJA. 2008. Plantas Medicinais no Brasil: nativas e exóticas. 2. ed.Nova Odessa, Instituto Plantarum.

[23] Souza CD, Felfili JM. 2006. Uso de plantas medicinais na região de Alto Paraiso de Goiás, GO, Brasil. Acta Botanica Brasílica, São Paulo, v.20, n.1, p.135-142.

[24] Badke MR. 2008. Conhecimento popular sobre o uso de plantas medicinais e o cuidado de enfermagem: Área de concentração Cuidado Educação e Trabalho em Enfermagem e Saúde. 68f. Mestrado Pós-Graduação em Enfermagem - Universidade Federal de Santa Maria.

[25] Brandão CR. 1986. Saber de classe e educação popular. IN: O ardil da ordem. Campinas: Papirus, 2ed. p.9-39.

[26] Junqueira MGP. 2005. Utilização de plantas medicinais pela população do Vale do Gamarra- Baependi- MG. 2005. 31 f. Monografia. Pós- Graduação Lato Sensu em Plantas Medicinais - Departamento de Agricultura, Universidade Federal de Lavras.

[27] Machado FRS, Pinheiro R, Guizard FL 2006. As Novas Formas de Cuidado Integral nos Espaços Públicos de Saúde. In: Cuidado - As Fronteiras da Integralidade. São Paulo- Rio de Janeiro. Hucitec-Abrasco, p. 57-74.

[28] Brasil "Ministério da Saúde". 2011. RENISUS, Disponível

em:<http://portal.saude.gov.br/portal/saude/profissional/v 
isualizar_texto.cfm?idtxt $=30780>$. Acesso em 31-052011.

[29] Amorim JA. 1999. Fitoterapia popular e a saúde da comunidade diagnóstico da proposta de integração no serviço de saúde em Campinas Grande, Paraíba, Brasil. Biblioteca Virtual em Saúde, São Paulo, s.n; p.316.

[30] Arnous AH, Santos AS, Beinner RPC. 2005. Plantas medicinais de uso caseiro-conhecimento popular e interesse por cultivo comunitário. Revista Espaço para a Saúde, Londrina, v.6, n.2, p.1-6.

[31] Tomazzoni MI, Negrell RR, Centa ML. 2006. Fitoterapia popular: a busca instrumental enquanto prática terapêutica. Textos e ContextosEnferm, Florianópolis, v.15, n.1, p.115-121.

[32] Prance GT. 1991. What is ethnobotany today? Journal of Ethnopharmacol, v.32, s.n, p.209.

[33] Bruhn JG. 1989. The use of natural products in modern medicine.Acta Pharm. Nord, v.1, p.117-131.

[34] Prance GT. 1987. Quantitative ethnobotany, and Amazonian conservation. Conservation Biology, v.8, s.n, p.225-228.

[35] Ferro D. 2006. Fitoterapia: conceitos clínicos. São Paulo. Atheneu, p.502.

[36] Araújo FD. 1998. Etnobotânica e botânica econômica: progressos nos últimos anos. In: FONSECA et al. organizadores, Etnobotânica, base para a conservação.I workshop brasileiro de Etnobotânica e Botânica Econômica. Nova Friburgo, RJ: EDUR, p.9-49.

[37] Moussa F, Leras E, Couturier G, Kahn F. 1998. Alguns aspectos metodológicos em botânica econômica: caso das palmeiras amazônicas. In: Fonseca et al. Organizadores. Etnobotânica, bases para a conservação. I Workshop Brasileiro de Etnobotânica e Botânica Econômica. Nova Friburgo, RJ: EDUR, P. 9-49.

[38] Padoch C, Jong W. 1990. Santa Rosa: the impact of the forest products trade on an Amazonian place and population.Advances in Economic Botany, v.6, p.214224.

[39] Pasa MC, Soares JJ, Guarim N, G. 2005. Estudo etnobotânico na comunidade de Conceição-Açu alto da bacia do rio Aricá Açu, MT, Brasil. Acta Botanica Brasílica, v.19, n.2, p.195-207.

[40] Pinto EPPP, Amorozo MCM, Furlan A. 2006. Conhecimento sobre plantas medicinais em comunidade rurais de Mata Atlântica-Itacaré, BA. Brasil. Acta Botanica Brasílica, V.20, n.4, p.751-762.

[41] King SR, Tempesta MS. 1994. Em Ciba Foundation Symposium. Wiley: Chichester, v.154, s.n, p. 197.

[42] Cotton CM. 1996. Ethnobotany: principles and applications.New York: J. Wiley, p.320.

[43] Balick MJ, Cox PA. 1977. Plants, people, and culture. New York: Scientific American Library.

[44] Giraldi M, Hanazaki N. 2010. Uso e conhecimento tradicional de plantas medicinais no sertão do Ribeirão, Florianópolis, SC, Brasil. Acta Botanica Brasílica, v.24, n.2, p.395-406.

[45] Ming LC, Hidalgo AF, Silva MAS, Silva SMP, Chaves FCM. 2000. Espécies Brasileiras com potencial alimentar: uso atual e desafios. In: Cavalcanti TB., Org.. Tópicos atuais em botânica: Palestras convidadas do $51^{\circ}$ Congresso Nacional de Botânica. Brasília: Embrapa, p.268-273.

[46] Gottlieb OR, Borin MRMB, Pagotto CLAC, Zocher, DHT. 1998. Biodiversidade: o enfoque interdisciplinar brasileiro. Ciência \& Saúde Coletiva, v.3, n.2, p.97-102.
[47] Damaceno AA, Barbosa AAA. 2008. Levantamento etnobotânico de plantas do Bioma cerrado na comunidade de Martinésia, Uberlândia, MG. Horizonte Cientifico, v.2, n.1.

[48] Ramos SA. 1997. In: SALES et al. Horto medicinal do cerrado. 2 ed. Brasília: JBB, p.1-3.

[49] Ribeiro JF, Walter BMT. 1998. Fitofisionomias do bioma Cerrado. Pp. 89-166. In: S.M. Sano \& S.P. Almeida eds.. Cerrado: ambiente e flora. Planaltina, Embrapa - CPAC.

[50] Dias BFS. 1990. Conservação da natureza no cerrado brasileiro. In. PINTO, N. M. Ed..Cerrado: caracterização, ocupação e perspectivas. Brasília: Un B/SEMATEC, p.583-640.

[51] Bruhn JG, Holmstedt B. 1982. "Ethnopharmacology, objectives, principles and perspectives". In: Natural products as medicinal agents. Stuttgart: Hippokrate.

[52] Amorozo MCM, Gely A. 1988. Uso de plantas medicinais por caboclos do Baixo Amazonas, Barcarena, PA, Brasil. Boletim do Museu Paraense Emílio Goeldi: Série Botânica, v.4, n.1, p.47-131.

[53] Elisabetsy E, Wannmacher L. 1993. The status of Ethnopharmacology in Brazil. Journal of Ethnopharmacology, v.38, p.137-147.

[54] Oliveira EB. 2008. Estudo Etnofarmacológico de Plantas Medicinais em Rosário da Limeira- MG. 2008. 99f. Tese. Universidade Federal de Viçosa, Minas Gerais.

[55] Boscolo OH, Valle LS. 2008. Plantas de uso medicinal em Quissamã, Rio de Janeiro, Brasil. Iheringia, Ser. Bot., Porto Alegre, v.63, n.2, p.263-277.

[56] Rodrigues E, Carlini ELA 2003. Levantamento etnofarmacológico realizado entre um grupo de quilombolas do Brasil. ArquivosBrasileiros de FitomedicinaCientífica, v.1, n.2, p.80-87.

[57] Elisabetsky E, Souza GC. 2004. Etnofarmacologia como ferramenta na busca de substância ativas. In: Simões, C. M. O.;Schenkel, E. P.; Gosmann, G. Mello, J. C.P.; Mentz, L. A.; Petrovick, P. R. Farmacognosia: da planta ao medicamento. 5. ed. rev. ampl. Porto Alegre/Florianopolis: Editora da UFRGS/ Editora da UFSC.

[58] Esterci N. 2008. População tradicional. In: Ricardo, B. \& CAMPANILLI, M. eds.. Almanaque Brasil Socio Ambiental. São Paulo, ISA.

[59] Junqueira MGP. 2005. Utilização de plantas medicinais pela população do Vale do Gamarra- Baependi- MG. 31 f. Monografia. Pós- Graduação Lato Sensu em Plantas Medicinais - Departamento de Agricultura, Universidade Federal de Lavras.

[60] Morais SM, Dantas JDP, Silva ARA, Magalhâes EF. 2005. Plantas medicinais usadas pelos índios Tapebas do Ceará. Revista Brasileira de Farmacognosia. Brazilian Journal of Pharmacognosy, v.15, n.2, p.169-17.

[61] Lopes JM, Sangalli A, Rojas TR. 2011. O uso de plantas medicinais tradicional na aldeia Jaguapirú. Disponível em: <http://www.rededesaberes.org. $>$.Acesso em 10-042011.

[62] Amorozo MCM. 1996. A abordagem etnobotânica na Pesquisa de Plantas medicinais. In: DI STASI, L. C. Org.. Plantas medicinais: Arte e Ciência. Um guia de estudointerdisciplinar. São Paulo: EDUSP, p. 47-68.

[63] Sales GPS, Albuquerque HN, Cavalcanti MLF. 2009. Estudo do uso de plantas medicinais pela comunidade quilombolas Senhor do Bonfim-Areia-PB. Revista de Biologia e Ciência da terra, n.1-2 semestre, p.31-36. 
[64] Mendieta MC, Vargas NR, Souza ADZ, Vanini M, Heck RM. 2011. Plantas medicinais utilizadas por comunidade quilombolas do município de Mostardas para hipertensão arterial. XII EMPOS II Mostra Cientifica, 2010. Disponível em: http://www.ufpel.edu.br/cic/2010/cd/pdf/CS/CS_00138.p df. Acesso em:07-05-2011.

[65] Amorozo MCM. 2002. Uso e diversidade de plantas medicinais em Santo Antonio do Leveger, MT, Brasil. Acta Botanica Brasilica, v.16, n.2, p.189-203.

[66] Rodrigues VEG, Carvalho DA. 2001. Levantamento etnobotânico de plantas medicinais em domínio do cerrado na região do Alto Rio Grande, Minas Gerais. Ciênc. Agrotec.,Lavras, v.25, n.1, p.102-123.

[67] Martins ER, Castro DM, Castellani DC, Dias JE. 2000. Plantas medicinais. Viçosa. Editora UFV: Universidade Federal de Viçosa, 220p.

[68] Instituto socioambiental. 2011. Disponível em: <www.socioambiental.org.br.>. Acesso em: 20-04-2011.

[69] Albuquerque UP, Lucena RFP. 2004. Métodos e técnicas para a coleta de dados. Pp. 37-62. In: U.P. Albuquerque \& R.F.P. Lucena orgs.. Métodos e técnicas na pesquisa etnobotânica. Recife, EditoraLivroRápido/NUPEEA.

[70] Posey DA. 1987. Etnobiologia: teoria e prática. Suma etnobiológica Brasileira, Etnobiologia. Petrópolis, v. 1.

[71] Amorozo MCM, Viertler RB. 2008. A abordagem qualitativa na coleta e análise de dados etnobotânicos. Pp.73-91. In: Albuquerque UP, Lucena RFR. \& Cunha, LVFCC. orgs. Métodos e Técnicas na Pesquisa Etnobotânica. 2. ed. Recife, COMUNIGRAF.

[72] Carlini E. 1983. A pesquisa com plantas medicinais usadas em medicina popular. Revista Associação. Medidicinal Brasileira, v.29, n.519, p.109-110.

[73] Elizabetsky E. 1987. Pesquisa com plantas medicinais. Ciência e Cultura, v. 39, n.8, p.67-702.

[74] Souza BARM, Souza BA. 1993. A forty years of Brazilian medical plant research. J. Ethnopharmacol, v.39, p.53-57.

[75] Ming LC. 1996. Coleta de plantas medicinais. In: DI STASI, L. C. Org..Plantas medicinais: Arte e Ciência, um guia de estudo interdisciplinar. São Paulo: EDUSP, p.6986.

[76] Vieira RF, Silva SR, Alves RBN, Silva DB, Wetzel MMVS, Dias TAB. Udry MC, Martins RC. 2002. Estratégias para a Conservação e Manejo de Manejo de Recursos Genéticos de Plantas Medicinais e Aromáticas. Resultados da $1^{\text {a }}$ Reunião Técnica. Brasília: Embrapa Recursos Genéticos e Biotecnologia/ Instituto Brasileiro de Meio Ambiente e dos Recursos Naturais Renováveis IBAMA/ Conselho Nacional de Desenvolvimento Científico e Tecnológico CNPq, p.184.

[77] Borba AM, Macedo M. 2006. Plantas medicinais usadas para a saúde bucal pela comunidade do bairro Santa Cruz, Chapadas dos Guimarães, MT, Brasil. Acta Botanica Brasílica, São Paulo, v.20, n.4, p.771-782.
[78] Savastano MAP, Di stasi LC. 1996. Folclore: conceitos e metodologia. In: Plantas medicinais: Arte e Ciência. Um guia de estudointerdisciplinar. São Paulo: EDUSP, p.3745.

[79] Bernard HR. 1988. Research methods in cultural anthropology. London: Sage.

[80] Almeida CFCBR, Albuquerque UP. 2002. Uso e conservação de plantas e animais medicinais no estado de Pernambuco Nordeste do Brasil: um estudo de caso. Interciência, v. 27, n.6.

[81] Santos JL, Amorozo MCM, Ming LC 2008. Uso popular de plantas medicinais na comunidade rural de Vargem Grande, município de Natividade da Serra, SP. Revista Brasileira de Plantas Medicinais, Botucatu, v.10, n.3, p.67-81.

[82] Dantas VS, Dantas IV, Chaves TP, Felismino DC, Silva H, Dantas GS. 2008. Análise das garrafadas indicadas pelos raizeiros na cidade de Campina Grande-PB. BIOFAR: revista de biologia de farmácia, p.1983-4209, v. 03, n.01.

[83] Silva AB, Souza MF, Silva, A. B.; Silva AHB. 2011. Plantas medicinais da caatinga mais comercializadas em feiras livres, Jequié, Bahia. Disponível em :http://www.abhorticultura.com.br/biblioteca/arquivos/Do wnload/Biblioteca/46_0657.pdf. Acesso em 25-10-2011.

[84] Alves RRN, Silva ALAG, Souto WMS, Barboza RRD. 2007. Utilização e comércio de plantas medicinais em campina grande, PB, Brasil. Revista eletrônica de farmácia. v.4, n.2, p.175-198.

[85] Freire AM, Santos JP, Ferreira LMR. 2009. Plantas medicinais e ritualísticas comercializadas em mercados e feiras livres em Juazeiro do Norte, CE, Brasil. IX CONGRESSO DE ECOLOGIA DO BRASIL, 13 a 17 de Setembro de 2009, São Lourenço - MG. Anais. Minas Gerais.

[86] Lopes TC, Lima WC. 2010. Erveiros as do Ver-o-Peso, em Belém do Pará: um estudo etnográfico. Revista África e Africanidades, ano 3, n.9, maio, p.1983-2354.

[87] Ustulin M, Figueiredo, BB, Tremea C, Pott A, Pott VJ, Bueno NR, Castilho RO. 2009. Plantas medicinais comercializadas no Mercado Municipal de Campo Grande-MS. Revista Brasileira de Farmacognosia Brazilian Journal of Pharmacognosy, v.19, n.3, p.805813.

[88] Nunes GP, Silva MF, Resende UM, Siqueira JM. 2003. Plantas medicinais comercializadas por raizeiros no Centro de Campo Grande, Mato Grosso do Sul. Rev. Bras. Farmacogn, v.13, n.2.

[89] Lima EPR, Maia MS, Matos WR. 2009. Levantamento das plantas medicinais comercializadas na feira livre do município de Duque de Caxias, Rio de Janeiro, Brasil. Saúde\&Amb. Rev. Duque de Caxias, v.4, n.2, p.34-39.

[90] Valentini CMA, Coelho MFB, Ortíz CER, Almeida JD. 2009. Uso e conservação da negraminaSiparuna guianensis Aubl. em Bom Sucesso, Várzea Grande-MT. INTERAÇÕES. Campo Grande, v.10, n.2, p.195-206. 